\title{
Total Syntheses of Conformationally Locked Difluorinated Pentopyranose Analogues and a Pentopyranosyl Phosphate Mimetic
}

\author{
Jonathan A. L. Miles, ${ }^{\dagger}$ Lisa Mitchell, ${ }^{\dagger}, \pitchfork$ Jonathan M. Percy, ${ }^{*, \dagger}$ Kuldip Singh, ${ }^{\dagger}$ \\ and E. Uneyama ${ }^{\dagger}$ \\ Department of Chemistry, University of Leicester, University Road, Leicester LE1 7RH, U.K., \\ and Department of Pure and Applied Chemistry, WestCHEM, University of Strathclyde, \\ Thomas Graham Building, 295 Cathedral Street, Glasgow G1 1XL, U.K.
}

jonathan.percy@strath.ac.uk

Received September 30, 2006

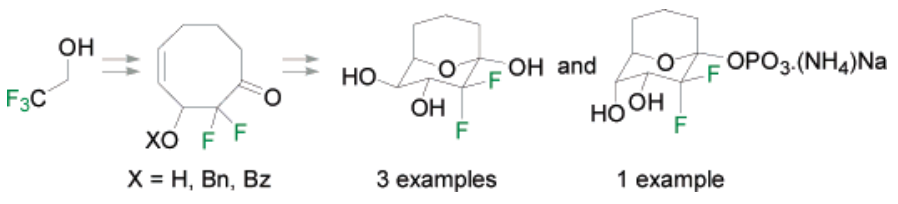

Trifluoroethanol has been elaborated, via a telescoped sequence involving a metalated difluoroenol, a difluoroallylic alcohol, [2,3]-Wittig rearrangement, and ultimately an RCM reaction and requiring minimal intermediate purification, to a number of cyclooctenone intermediates. Epoxidation of these intermediates followed by transannular ring opening or dihydroxylation, then transannular hemiacetalization delivers novel bicyclic analogues of pentopyranoses, which were elaborated (in one case) to an analogue of a glycosyl phosphate.

\section{Introduction}

Saccharide recognition is a key event in a wide range of biological processes. Sugars present arrays of hydroxyl groups in a spatially defined manner, and proteins bind to and distinguish between different saccharides by forming complex

\footnotetext{
University of Leicester.
\#niversity of Strathclyde.

(1) (a) Loganathan, D.; Aich, U. Glycobiology 2006, 16, 343. (b) Laederach, A.; Reilly, P. J. Proteins: Struct., Funct., Bioinf. 2005, 60, 591. (c) Carcabal, P.; Jockusch, R. A.; Hunig, I.; Snoek, L. C.; Kroemer, R. T.; Davis, B. G.; Gamblin, D. P.; Compagnon, I.; Oomens, J.; Simons, J. P. J. Am. Chem. Soc. 2005, 127, 11414. (d) Flint, J.; Bolam, D. N.; Nurizzo, D.; Taylor, E. J.; Williamson, M. P.; Walters, C.; Davies, G. J.; Gilbert, H. J. J. Biol. Chem. 2005, 280, 23718. (e) Fernandez, M. D.; Canada, F. J.; Jimenez-Barbero, J.; Cuevas, G. J. Am. Chem. Soc. 2005, 127, 7379. (f) Mitchell, E. P.; Sabin, C.; Snajdrova, L.; Pokorna, M.; Perret, S.; Gautier, C.; Hofr, C.; Gilboa-Garber, N.; Koca, J.; Wimmerova, M.; Imberty, A. Proteins: Struct., Funct., Bioinf. 2005, 58, 735. (g) Loris, R.; Imberty, A.; Beeckmans, S.; Van, Driessche, E.; Read, J. S.; Bouckaertt, J.; De Greve, H.; Buts, L.; Wyns, L. J. Biol. Chem. 2003, 278, 16297. (h) Vyas, N. K.; Vyas, M. N.; Chervenak, M. C.; Bundle, D. R.; Pinto, B. M.; Quiocho, F. A. Proc. Natl. Acad. Sci. U.S.A. 2003, 100, 15023. (i) Pathiaseril, A.; Woods, R. J. J. Am. Chem. Soc. 2000, 122, 331. (j) Zacharias, M.; Straatsma, T. P.; McCammon, J. A.; Quiocho, F. A. Biochemistry 1993, 32, 7428. (k) Quiocho, F. A. Biochem. Soc. Trans. 1993, 21, 442. (1) Jimenez-Barbero, J.; Canada, F. J.; Cuevas, G.; Asensio, J. L.; Aboitiz, N.; Canales, A.; Chavez, M. I.; Fernandez-Alonso, M. C.; Garcia-Herrero, A.; Mari, S.; Vidal, P. NMR Spectroscopy and Computer Modeling of Carbohydrates: Recent Advances; ACS Symposium Series 930; American Chemical Society: Washington, DC, 2006; p 60. (m) Bryce, R. A.; Hillier, I. H.; Naismith, J. H. Biophys. J. 2001, 81, 1373.
}

networks of hydrogen bonds to them. ${ }^{1}$ The core six-membered oxacycle in pyranose sugars also exerts a significant effect on a range of conformational properties via the anomeric effect. ${ }^{2}$ The linkages between sugars in di- and higher saccharides are acetals, and a wide range of glycosyltransferases and glycosidases exist to synthesize and cleave those linkages, respectively. Saccharide mimetics, ${ }^{3}$ which present hydroxyl groups in a useful manner but cannot be cleaved from their sites of attachment by glycosidases, could be useful probes of sugar-processing enzymes. If the mimetics lack the pyranose oxygen and therefore the anomeric effect, different conformers could become available.

Many groups have described the synthesis of five-, six-, and seven-membered carbocyclic analogues of saccharides. More recently, highly functionalized cyclooctane derivatives have attracted attention as ring-expanded analogues (Chart 1). The Sinay group combined the ideas of the stability of carbasugars with the potential for occupying uncharted conformational space, synthesizing $\mathbf{1}$, which was shown by NOE to occupy a boatchair conformation related to that of the corresponding galac-

(2) (a) Kirby, A. The Anomeric Effect and Related Stereoelectronic Effects at Oxygen; Springer-Verlag: Berlin, 1983. (b) For recent mechanistic studies, see: Bennet, A. J.; Kitos, T. E. J. Chem. Soc., Perkin Trans. 2002, 2, 1207. (c) For a computational examination of the mechanism, see: Dimelow, R. J.; Bryce, R. A.; Masters, A. J.; Hillier, I. H.; Burton, N. A. J. Chem. Phys. 2006, 124. (d) Mohr, M.; Bryce, R. A.; Hillier, I. H. J. Phys. Chem. A 2001, 105, 8216. 


\section{CHART 1}

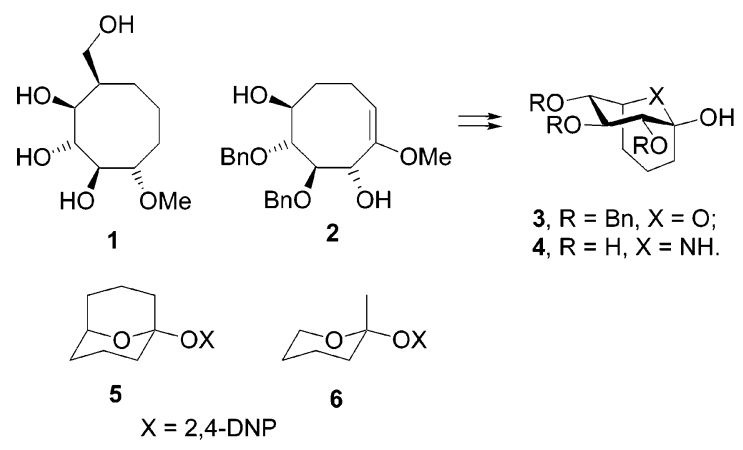

topyranose. ${ }^{4}$ The synthesis used carbohydrate starting materials to provide most of the functionality in the products and ensure stereocontrol, exploiting a Lewis acid mediated ring-expanding Claisen rearrangement (described originally by Paquette) as the key step. More recently, Paquette has shown that zirconocenepromoted ring contraction can be used to convert vinylfuranosides to cyclooctane polyols via vinyl cyclobutanones, and a $[3,3]$-sigmatropic rearrangement again secures the carbocycles. ${ }^{5}$ Using a quite different approach, Mehta and co-workers have shown that unsaturated eight-membered ring compounds such as cyclooctatetraene can be elaborated controllably to the corresponding polyols. ${ }^{6}$

The ring-expanding Claisen rearrangement also allows the synthesis of masked cyclooctanones 2. Van Boom and the Leiden group exploited transannular strain-relieving nucleophilic attack upon a ketone carbonyl group to close a number of bicyclic systems, which provide conformationally locked analogues of sugars 3 and azasugars 4. ${ }^{7}$ The bicyclic array is very interesting because of the extremely low reactivity of the pseudoglycosidic bond. Kirby and co-workers showed that $\mathbf{5}$ was $10^{13}$ times less reactive than $\mathbf{6}$ because of the way the bicyclic architecture opposes stabilization of developing positive charge at the pseudoanomeric carbon through oxacarbenium ion formation as the pseudoglycosidic bond stretches toward cleavage. ${ }^{8}$ The idea of using conformational locking to allow mimicry

(3) (a) Haneda, T.; Goekjian, P. G.; Kim, S. H.; Kishi, Y. J. Org. Chem. 1992, 57, 490. (b) Goekjian, P. G.; Wu, T. C.; Kang, H. Y.; Kishi, Y. J. Org. Chem. 1991, 56, 6422. (c) Kuntz, D. A.; Ghavami, A.; Johnston, B. D.; Pinto, B. M.; Rose, D. R. Tetrahedron: Asymmetry 2005, 16, 25. (d) Yang, G. L.; Schmieg, J.; Tsuji, M.; Franck, R. W. Angew. Chem., Int. Ed. 2004, 43, 3818. (e) Mikkelsen, L. M.; Hernaiz, M. J.; Martin-Pastor, M.; Skrydstrup, T.; Jimenez-Barbero, J. J. Am. Chem. Soc. 2002, 124, 14940. For reviews, see: (f) Sears, P.; Wong, C. H. Angew. Chem., Int. Ed. 1999, 38, 2301. (g) Wong, C. H. Acc. Chem. Res. 1999, 32, 376.

(4) (a) Wang, W.; Zhang, Y. M.; Sollogoub, M.; Sinay, P. Angew. Chem., Int. Ed. 2000, 39, 2466. (b) Wang, W.; Zhang, Y. M.; Zhou, H. H.; Bleriot, Y.; Sinaÿ, P. Eur. J. Org. Chem. 2001, 1053.

(5) Paquette, L. A.; Zhang, Y. L. J. Org. Chem. 2006, 71, 4353.

(6) (a) Mehta, G.; Pallavi, K. Tetrahedron Lett. 2004, 45, 3865. (b) Mehta, G.; Pallavi, K. Chem. Commun. 2002, 2828. (c) For a review of earlier work, see: Mehta, G.; Singh, V. Chem. Rev. 1999, 99, 881.

(7) van Hooft, P. A. V.; Litjens, R.; van der Marel, G. A.; van Boeckel,

C. A. A.; van Boom, J. H. Org. Lett. 2001, 3, 731.

(8) Briggs, A. J.; Evans, C. M.; Glenn, R.; Kirby, A. J. J. Chem. Soc., Perkin Trans. 2 1983, 1637.

(9) For recent examples, see: (a) Bleriot, Y.; Vadivel, S. K.; Herrera, A. J.; Greig, I. R.; Kirby, A. J.; Sinay, P. Tetrahedron 2004, 60, 6813. (b) Lorthiois, E.; Meyyappan, M.; Vasella, A. Chem. Commun. 2000, 1829.

(10) (a) Audouard, C.; Fawcett, J.; Griffiths, G. A.; Percy, J. M.; Pintat, S.; Smith, C. A. Org. Biomol. Chem. 2004, 2, 528. (b) Audouard, C.; Fawcett, J.; Griffith, G. A.; Kerouredan, E.; Miah, A.; Percy, J. M.; Yang, H. L. Org. Lett. 2004, 6, 4269. (c) Kariuki, B. M.; Owton, W. M.; Percy, J. M.; Pintat, S.; Smith, C. A.; Spencer, N. S.; Thomas, A. C.; Watson, M. Chem. Commun. 2002, 228. (d) Butt, A. H.; Percy, J. M.; Spencer, N. S. Chem. Commun. 2000, 1691.
SCHEME 1. Outline of Sequence Showing the Development of NDP Sugar Analogues

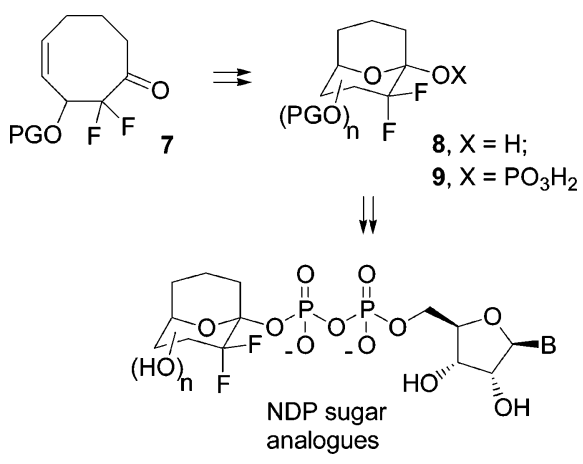

of conformations traversed at transition states has also been explored extensively. ${ }^{9}$

$\mathrm{We}^{10}$ and others ${ }^{11}$ have developed a number of approaches for the synthesis of fluorinated analogues of the molecules of nature from commercial fluorinated starting materials, in which RCM forms a key step. One of our projects aimed to develop a de novo route via difluorinated cyclooctenones 7 to conformationally locked difluorinated analogues $\mathbf{8}$ of pentoses and their phosphates 9, which we would advance ultimately to analogues of NDP sugars, with the global aim of the development of new chemical tools for the study of glycosyltransferase enzymes. The syntheses would start from sustainable fluorinated starting materials, avoiding the use of materials banned under the Montreal and Kyoto Protocols (Scheme 1). Although these protocols deal with large-scale production, they affect the availability and supply of materials for use on the laboratory scale; the development of a new methodology based on banned substances would therefore seem like nugatory effort.

The fluorine atoms would allow location of the compounds in vitro or in vivo by ${ }^{19} \mathrm{~F} \mathrm{NMR}$, and they could report conformational changes in the hydroxyl-bearing ring through ${ }^{3} J_{\mathrm{H}-\mathrm{F}}$ coupling constants. ${ }^{12}$ In our preliminary publications, we showed how we could use metalated difluoroalkene chemistry to advance trifluoroethanol rapidly to precursors to eightmembered rings and then close them via $\mathrm{RCM}^{13}$ to afford difluorinated cyclooctenones, templates for stereoselective oxidation (dihydroxylation ${ }^{14}$ or epoxidation ${ }^{15}$ ), and transannular reactions. These preliminary findings delivered a number of model polyol systems which contain the distinctly unnatural gem-dimethyl and $N, N$-diethylcarbamoyloxy groups, which we now wished to delete. We wished to explore a route, which would avoid the use of strong base/low-temperature conditions

(11) (a) Fustero, S.; Catalan, S.; Piera, J.; Sanz-Cervera, J. F.; Fernandez, B.; Acena, J. L. J. Org. Chem. 2006, 71, 4010. (b) Fustero, S.; SanchezRosello, M.; Jimenez, D.; Sanz-Cervera, J. F.; del Pozo, C.; Acena, J. L. J. Org. Chem. 2006, 71, 2706. (c) Fustero, S.; Bartolome, A.; Sanz-Cervera, J. F.; Sanchez-Rosello, M.; Soler, J. G.; de Arellano, C. R.; Fuentes, A. S. Org. Lett. 2003, 5, 2523. (d) Yang, Y. Y.; Meng, W. D.; Qing, F. L. Org. Lett. 2004, 6, 4257. (e) You, Z. W.; Wu, Y. Y.; Qing, F. L. Tetrahedron Lett. 2004, 45, 9479. (f) De Matteis, V.; van Delft, F. L.; de Gelder, R.; Tiebes, J.; Rutjes, F. Tetrahedron Lett. 2004, 45, 959. (g) Marhold, M.; Buer, A.; Hiemstra, H.; van Maarseveen, J. H.; Haufe, G. Tetrahedron Lett. 2004, 45, 57 .

(12) Thibaudeau, C.; Plavec, J.; Chattopadhyaya, J. J. Org. Chem. 1998, $63,4967$.

(13) Griffith, G. A.; Percy, J. M.; Pintat, S.; Smith, C. A.; Spencer, N.; Uneyama, E. Org. Biomol. Chem. 2005, 3, 2701.

(14) Fawcett, J.; Griffiths, G. A.; Percy, J. M.; Pintat, S.; Smith, C. A.; Spencer, N.; Uneyama, E. Chem. Commun. 2004, 302.

(15) Fawcett, J.; Griffith, G. A.; Percy, J. M.; Uneyama, E. Org. Lett. 2004, 6, 1277. 
SCHEME 2. Retrosynthetic Analysis of Key Cyclooctenone 14

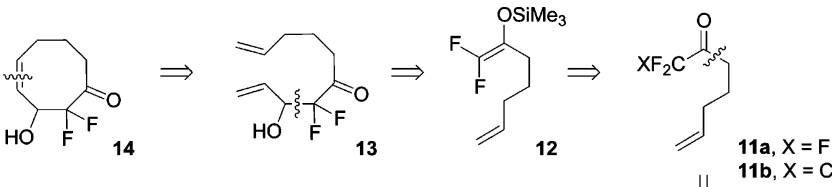

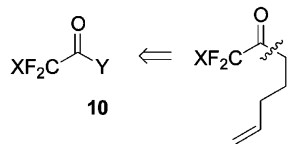

SCHEME 3. Attempted Halodifluoromethyl Ketone Syntheses

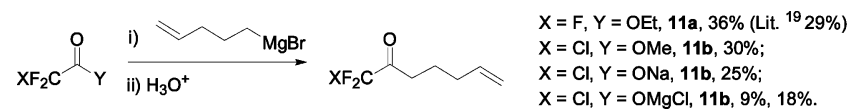

if possible and minimize the number of purifications in the sequences, to complete syntheses of a number of analogues of sugar-like and an illustrative phosphate monoester through stereoselective oxidation reactions and the development of an effective phosphorylation strategy. We report the results of these studies in this manuscript.

\section{Results and Discussion}

Attempted Development of a Scaleable Route Based on Reductive Dehalogenation. Scheme 2 shows the retrosynthetic analysis carried out for $\mathbf{1 4}$ from key intermediate $\alpha, \alpha$-difluoro$\beta$-hydroxy ketone 13. The literature describes a number of methods for the generation of difluorinated silyl enol ether 12, which could make $\mathbf{1 3}$ available through aldol chemistry under potentially scaleable conditions (Scheme 2).

Ishihara ${ }^{16}$ and Uneyama ${ }^{17}$ have described methods for the synthesis of difluoroenol silyl ethers such as $\mathbf{1 2}$ from chlorodifluoromethyl and trifluoromethyl ketones, respectively, so we prepared 11a and 11b from commercial 1-bromopent-4-ene via reaction of the Grignard reagent with electrophiles $\mathbf{1 0}$ derived from chlorodifluoroacetic or trifluoroacetic acids (Scheme 3). ${ }^{18}$ These starting materials are available at low cost and appear to be sustainable.

Typical reaction conditions for this type of perhalomethylketone synthesis use ester electrophiles or, alternatively, an excess of Grignard reagent and the free acid. ${ }^{18}$ The latter procedure would waste a moderately expensive bromide, so we preformed the sodium or magnesium salts using $\mathrm{NaH}$ or $i-\mathrm{PrMgCl}$.

A large number of unsuccessful experiments are summarized in the Scheme. The ketones were isolated by distillation after careful extraction of the product into pentane/diethyl ether, and hydration of the ketones was a distinct problem during these procedures. The poor yield of the trifluoromethyl ketone was comparable to that obtained by Laurent and co-workers. ${ }^{19} \mathrm{We}$ were unable to synthesize $\mathbf{1 2}$ in more than trace amounts from either 11a or 11b under published ( $\mathrm{Zn}, \mathrm{Me}_{3} \mathrm{SiCl}, \mathrm{MeCN}, \Delta$ or excess $\mathrm{Mg} / \mathrm{Me}_{3} \mathrm{SiCl}, \mathrm{DMF}$ ) conditions. Uneyama ${ }^{17}$ has reported

(16) Yamana, M.; Ishihara, T.; Ando, T. Tetrahedron Lett. 1983, 24, 507.

(17) (a) Amii, H.; Kobayashi, T.; Hatamoto, Y.; Uneyama, K. Chem. Commun. 1999, 1323. (b) For a review, see: Uneyama, K.; Amii, H. J. Fluorine Chem. 2002, 114, 127.

(18) Kuroboshi, M.; Ishihara, T. Bull. Chem. Soc. Jpn. 1990, 63, 428.

(19) Felix, C.; Laurent, A.; Mison, P. J. Fluorine Chem. 1995, 70, 71.
SCHEME 4. Cyclooctenone Syntheses Based on Metalated Difluoroenol Acetal Chemistry
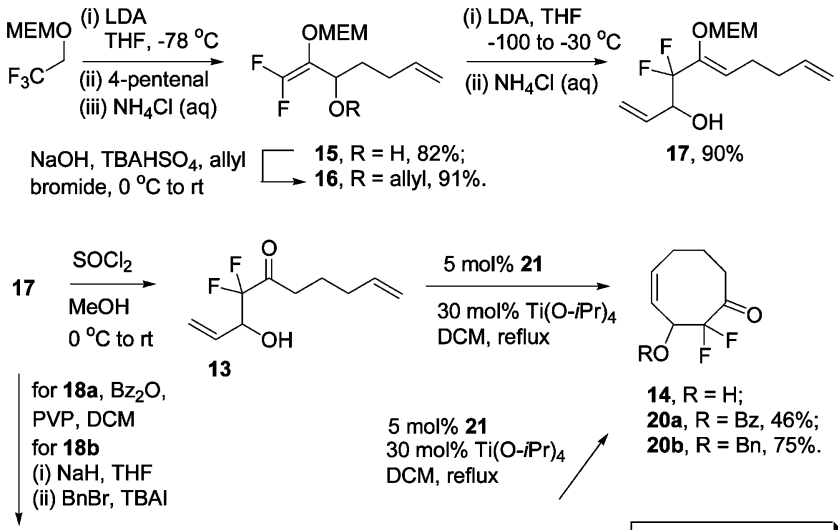

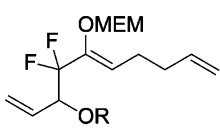

$18 \mathrm{a}, \mathrm{R}=\mathrm{Bz}, 80 \%$

$18 b, R=B n, 92 \%$.

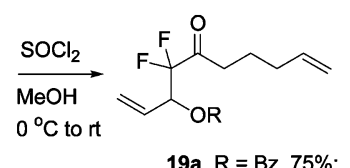

$19 b, R=B n, 94 \%$

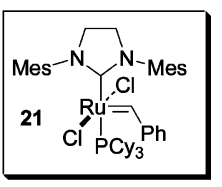

that aliphatic trifluoromethyl ketones undergo slow reductive defluorination under the latter conditions; for 11a, the reaction was prohibitively slow. We also attempted to use the conditions described by Ishihara ${ }^{18}$ for direct aldol reaction between 11b and acrolein or cinnamaldehyde. The best result (ca. 10\% conversion) was obtained with the latter electrophile despite considerable efforts to optimize the reactions, which stopped at very low conversion, and we were not able to isolate any of 13. We therefore decided to use our metalated difluoroenol chemistry to develop a working strategy to the target aldol.

Successful Dehydrofluorination/Metalation Route. Known ${ }^{20}$ difluoroallylic alcohol 15 was synthesized in good yield (82\%, $20 \mathrm{~g}$ scale) using our published procedure from the MEM-ether of trifluoroethanol and 4-pentenal (Scheme 4). ${ }^{21}$ The Kugelrohrdistilled alcohol was allylated under phase-transfer conditions ${ }^{22}$ to ether $16(91 \%)$ and progressed without further purification (Scheme 4).

The rearrangement of $\mathbf{1 6}$ took place over $4 \mathrm{~h}$ on warming from -100 to $-30{ }^{\circ} \mathrm{C}$, and chromatography of the product returned a disappointing yield of pure 17 (ca. 30\%) initially. We were able to purify hydroxyketone $\mathbf{1 3}$ (following enol ether cleavage $^{23}$ ) by Kugelrohr distillation improving the yield to $50 \%$ over the two steps and removing two chromatographic purifications from the sequence if the enol ether was cleaved directly from crude [2,3]-Wittig product. In the RCM reaction $(5 \mathrm{~mol}$ $\%$ of $21,30 \mathrm{~mol} \%$ of $\mathrm{Ti}(\mathrm{O}-i \mathrm{Pr})_{4}, 5 \mathrm{mM}$ in DCM), starting material appeared to be consumed completely within $2 \mathrm{~h}$ but the volatile cyclooctenone product $\mathbf{1 4}$ was difficult to isolate. Careful removal of the dichloromethane solvent by distillation at atmospheric pressure and then eluting the residue through a polymer-bound thiol SPE tube with methanol afforded the product in modest (estimated 60\%) yield. This first-generation synthesis provides proof of concept but delivered a rather

(20) Griffith, G. A.; Hillier, I. H.; Percy, J. M.; Roig, R.; Vincent, M. A. J. Org. Chem. 2006, 71, 8250.

(21) Patel, S. T.; Percy, J. M.; Wilkes, R. D. Tetrahedron 1995, 51, 9201.

(22) Patel, S. T.; Percy, J. M.; Wilkes, R. D. J. Org. Chem. 1996, 61, 166.

(23) Broadhurst, M. J.; Brown, S. J.; Percy, J. M.; Prime, M. E. J. Chem Soc., Perkin Trans. 1 2000, 3217. 


\section{CHART 2}

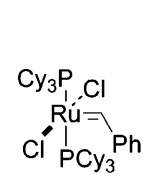

22

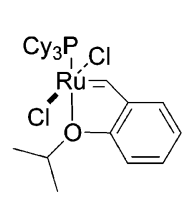

23

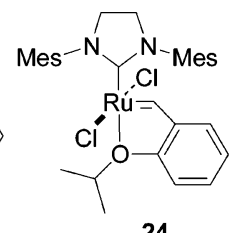

24

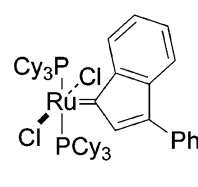

25 volatile product, which was not easy to characterize fully, in ca. $20 \%$ overall yield from trifluoroethanol.

We therefore sought to optimize the sequence. The [2,3]Wittig step afforded good estimated yields (ca. 90\%) of up to 24 mmol of homoallylic alcohol $\mathbf{1 7}$ which was sufficiently pure by ${ }^{1} \mathrm{H}$ and ${ }^{19} \mathrm{~F}$ NMR spectra and GC-MS to take on directly. Material of the same quality could also be obtained by taking crude undistilled difluoroallylic alcohol through the allylation/ rearrangement sequence (after checking the purity from the ${ }^{1} \mathrm{H}$ and ${ }^{19} \mathrm{~F}$ NMR spectra). We esterified $\mathbf{1 7}$ by shaking with benzoic anhydride and polymer-supported base poly(4-vinylpyridine) in dichloromethane to afford 18a and then cleaved the MEM group directly from the crude material. Benzoate 19a was purified before RCM in the first round of reactions and underwent RCM (second-generation Grubbs' catalyst $21, \mathrm{Ti}(\mathrm{O} i \text { - } \mathrm{Pr})_{4}$ cocatalyst) to afford 20a in acceptable (46\%) yield after chromatography. We subsequently found that the unpurified precursor also underwent RCM in good yield. Trace contaminants of Ru could be removed by eluting the columned material through thiol SPE tubes with $\mathrm{MeOH}$. The entire sequence from the starting trifluoroethyl acetal therefore finally involves only a single purification, which is a column after RCM, and the overall yield of $\mathbf{2 0 a}$ is ca. $30 \%$ from trifluoroethanol. Rearrangement product 17 was also benzylated ( $92 \%$, using an excess of sodium hydride to ensure complete alkoxide formation), subjected to enol ether methanolysis (94\%), and taken through the RCM without purification to afford 20b in good $(75 \%)$ yield.

Though superficially less attractive than the Ishihara and Uneyama aldol syntheses because it contains two low-temperature steps, our route delivers gram-scale quantities of the RCM product reproducibly with $30 \mathrm{mmol}$ of material coming through the [2,3]-Wittig rearrangement (the most demanding step) and with minimal purification.

Developing Conditions for the RCM Reaction. Many of the $\mathrm{RCM}$ reactions ${ }^{24}$ which form medium rings $^{25}$ use relatively high loadings of ruthenium catalysts, suggesting that either catalytic efficiency is low or cyclizations are very slow, ${ }^{26}$ or both. We screened commercial precatalysts 21-25 (Chart 2) for the cyclization of $19 \mathbf{a}$ and $\mathbf{1 9 b}$ at an initial loading of 5 mol $\%$.

(24) For general reviews of RCM issues, see: (a) Conrad, J. C.; Fogg, D. E. Curr. Org. Chem. 2006, 10, 185. (b) Nicolaou, K. C.; Bulger, P. G.; Sarlah, D. Angew. Chem., Int. Ed. 2005, 44, 4490. (e) Furstner, A. Angew. Chem., Int. Ed. 2000, 39, 3013.

(25) For reviews of medium ring forming RCM, see: (a) Deiters, A.; Martin, S. F. Chem. Rev. 2004, 104, 2199. (b) Maier, M. E. Angew. Chem., Int. Ed. 2000, 39, 2073. (c) Yet, L. Chem. Rev. 2000, 100, 2963. (d) Michaut, A.; Rodriguez, J. Angew. Chem., Int. Ed. 2006, 45, 5740. For recent examples, see: (e) Bleriot, Y.; Giroult, A.; Mallet, J. M.; Rodriguez, E.; Vogel, P.; Sinay, P. Tetrahedron: Asymmetry 2002, 13, 2553. (f) Bourgeois, D.; Mahuteau, J.; Pancrazi, A.; Nolan, S. P.; Prunet, J. Synthesis 2000, 869. (g) Boyer, F. D.; Hanna, I.; Nolan, S. P. J. Org. Chem. 2001, 66, 4094. (h) Buono, F.; Tenaglia, A. J. Org. Chem. 2000, 65, 3869. (i) Furstner, A. Langemann, K. J. Org. Chem. 1996, 61, 8746. (j) Buszek, K. R.; Sato, N.; Jeong, Y. Tetrahedron Lett. 2002, 43, 181.

(26) Illuminati, G.; Mandolini, L. Acc. Chem. Res. 1981, 14, 95.
SCHEME 5. Attempted RCM with the Neolyst Catalyst

$19 \mathrm{a}$ or $19 \mathrm{~b}$

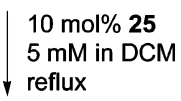

$20 \mathrm{a}$ or $20 \mathrm{~b}$
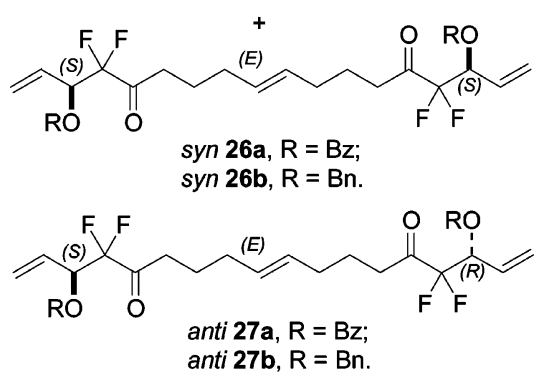

The reaction with Neolyst catalyst $\mathbf{2 5}^{27}(10 \mathrm{~mol} \%)$ returned significant quantities of homodimeric cross-metathesis products from 19a as a mixture of $C_{2}$-symmetric racemic syn and achiral and meso anti diastereoisomers $26 \mathbf{a}$ and $27 \mathbf{a}$, respectively, in moderate (34\% isolated from a possible $50 \%$ ) yield, along with recovered starting material $(42 \%)$ and traces of RCM product 20a (Scheme 5).

A similar result was observed from benzyl ether $19 \mathrm{~b}$ with the isolation of $\mathbf{2 6 \mathbf { b }}$ and $\mathbf{2 7 b}$ (38\% combined) along with recovered starting material $(36 \%)$ and a small amount of 20b (4\%). The reaction was started with a lower loading $(5 \%)$ of catalyst, followed by the addition of a further portion $(5 \%)$ when the reaction did not appear to proceed. The homodimerization was observed with and without the Ti(IV) cocatalyst.

The isolation of terminal alkene open-chain homodimers from an RCM reaction run at high dilution is relatively unusual. ${ }^{28}$ The ${ }^{1} \mathrm{H}$ NMR spectra obtained for the mixtures of $\mathbf{2 6}$ and $\mathbf{2 7}$ are relatively simple and highly symmetrical, consistent only with the formation of these dimers. The COSYs show the relationship between the vinylic proton of the symmetrical internal alkene and the allylic methylene protons clearly. The connectivity between the terminal alkene and the allylic methine is also established unambiguously. The $1 \mathrm{D}{ }^{1} \mathrm{H}$ and ${ }^{13} \mathrm{C} \mathrm{NMR}$ spectra fail to show the presence of the different stereoisomers clearly, though some of the methylene carbon signals are doubled. The 1D $\left\{{ }^{1} \mathrm{H}\right\}{ }^{19} \mathrm{~F}$ NMR spectrum appears to show the only difference between the diastereoisomers; formally, there are four ${ }^{19} \mathrm{~F}$ environments arising from two pairs of enantiotopic fluorines (two environments) in the achiral and meso stereoisomers and two pairs of homotopic fluorines (two environments) in the $C_{2}$-symmetric species (similar considerations apply to various protons, but the higher chemical shift range of fluorine nucleii reveals more subtle differences in environment). Though we observed four environments for $\mathbf{2 6} \mathbf{b} / \mathbf{2 7} \mathbf{b}$, there were seven for $\mathbf{2 6} \mathbf{a} / \mathbf{2 7} \mathbf{a}$; given the rather flexible nature of these extended

(27) Furstner, A.; Guth, O.; Duffels, A.; Seidel, G.; Liebl, M.; Gabor, B.; Mynott, R. Chem.-Eur. J. 2001, 7, 4811.

(28) (a) Creighton and co-workers identified an open-chain dimer by LC-MS from a mixture of products generated during a cyclooctannulation reaction: Creighton, C. J.; Du, Y. M.; Reitz, A. B. Bioorg. Med. Chem. 2004, 12, 4375. For recent applications, see: (b) Creighton, C. J.; Du, Y. M.; Santulli, R. J.; Tounge, B. A.; Reitz, A. B. Bioorg. Med. Chem. Lett. 2006, 16, 3971. (c) Abell, A. D.; Brown, K. M.; Coxon, J. M.; Jones, M. A.; Miyamoto, S.; Neffe, A. T.; Nikkel, J. M.; Stuart, B. G. Peptides 2005, 26, 251. 
molecules, conformational erosion of symmetry is perhaps unsurprising.

We were surprised by the homodimerization given the reports that this ruthenium indenylidene complex is particularly suitable for the formation of medium-sized rings by RCM. Indeed this (pre)catalyst is more effective at closing the eight-membered E-ring of Nakadomarin A 28 than either Grubbs' catalyst $\mathbf{2 1}$ or 22. ${ }^{27}$

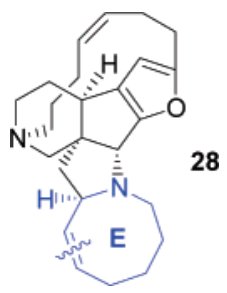

The effectiveness of Neolyst $\mathbf{2 5}$ for slow RCM reactions is attributed to higher stability in solution, though it is not clear if this refers to slow initial dissociation of phosphane, slow recapture of the catalytically active $14 \mathrm{e}$ complex, or slow second-order decomposition of the latter reactive species. ${ }^{29}$ It appears that the RCM is slow for $19 \mathbf{a}$ and $\mathbf{1 9 b}$ with this precatalyst and that $\mathbf{2 6}$ and $\mathbf{2 7}$, once formed, either are too unreactive to form $\eta^{2}$-complexes with the methylidene $14 \mathrm{e}$ complex which must now carry the chain or cannot progress to metallocyclobutanes from the $\eta^{2}$-complexes. The presence of phosphane, rather than the NHC ligand, is known to make metallocyclobutane formation less favorable. Relatively rapid consumption and recycling of $\mathbf{2 6}$ and $\mathbf{2 7}$ would be expected under these conditions. The internal alkene derives from cross metathesis between type I alkenes, ${ }^{30}$ which is normally fast, so we have observed an interruption of the normally rapid retrocross metathesis. Exposure of a purified 26b/27b mixture to 5 mol \% of $\mathbf{2 1}$ in the presence of the Ti(IV) cocatalyst resulted in $50 \%$ conversion to $\mathbf{2 0 b}$ after $18 \mathrm{~h}$ as the sole product by ${ }^{19} \mathrm{~F}$ NMR (the remainder was unreacted starting material). Mixing the crude product with a sample of authentic $\mathbf{2 0 b}$ and running the GC of the mixture resulted in a single peak being observed. Clearly, the retro-cross metathesis is not rapid under these conditions, even with the more reactive precatalyst $\mathbf{2 1}$.

Catalyst 22 alone will not catalyze RCM of any of our substrates; the presence of the Ti(IV) cocatalyst is required to achieve slow cyclization. Second-generation catalyst $\mathbf{2 1}$ is the most effective catalyst explored for the cyclooctannulation reaction, and despite the generally lower Lewis acidity of the alkylidene when the NHC ligand replaces phosphane, the Ti(IV) cocatalyst still exerted a small positive qualitative effect on the reaction outcome. Second-generation Grubbs-Hoveyda catalyst $^{31} \mathbf{2 4}$ showed comparable reactivity to $\mathbf{2 1}$ (in terms of apparent rate of consumption of 19a) but afforded a lower yield of eight-membered cyclic products under any given conditions due to oligomer formation, whereas the corresponding firstgeneration catalyst $\mathbf{2 3}$ was ineffective.

Scale-up requires reactions that can be run at concentrations approaching $0.01 \mathrm{M}$ or better, or the volumes of solvent required

(29) Sanford, M. S.; Love, J. A.; Grubbs, R. H. J. Am. Chem. Soc. 2001, $123,6543$.

(30) Chatterjee, A. K.; Choi, T. L.; Sanders, D. P.; Grubbs, R. H. J. Am. Chem. Soc. 2003, 125, 11360.

(31) (a) Kingsbury, J. S.; Harrity, J. P. A.; Bonitatebus, P. J.; Hoveyda, A. H. J. Am. Chem. Soc. 1999, 121, 791. (b) For a review, see: Hoveyda, A. H.; Gillingham, D. G.; Van Veldhuizen, J. J.; Kataoka, O.; Garber, S. B.; Kingsbury, J. S.; Harrity, J. P. A. Org. Biomol. Chem. 2004, 2, 8.
SCHEME 6. Dioxirane Oxidations

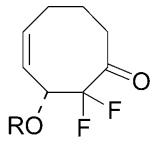

20b, $R=B n$. 20a, $R=B z$
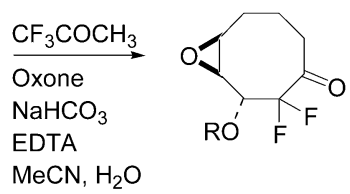

29a, 75\%; become prohibitive for normal laboratory equipment. We therefore sought to explore the effects of concentration upon the metathesis outcomes qualitatively. The RCM of benzoate 19a could be carried out successfully up to $20 \mathrm{mM}$, with dimerization and other side reactions starting at higher concentrations. This is a relatively high concentration compared to most of those used in the literature, and its use has allowed the preparation of gram quantities of material. Higher dilution was required for benzyl ether $19 b(2.5 \mathrm{mM})$ and alcohol $13(1 \mathrm{mM})$; significant quantities of side products were formed at $20 \mathrm{mM}$ in these cases. Quantitative aspects of these investigations will be presented elsewhere.

Elaboration of RCM Products to Protected Pentopyranose Analogues via Oxidation Transformations. Epoxides 29a and 29b were made using the dioxirane method of Yang $^{32}$ which was diastereofacially selective (Scheme 6). In the case of benzyl ether 20b, a trace of benzoate 29a was observed in the product consistent with oxidation at the benzylic methylene by the reactive dioxirane. ${ }^{33}$ The sharp ${ }^{19} \mathrm{~F}$ NMR spectra of the crude products showed the formation of a single diastereoisomer in each case with yield loss occurring on purification and removal of the hydrate of the trifluoroacetone. Neither product formed crystals of sufficient quality for the sense of stereoselection to be confirmed directly, but the size of $J$ between $\mathrm{H}-1$ and $\mathrm{H}-2$ provides a strong indication; at ca. $9 \mathrm{~Hz}$, it is more likely to arise from a trans pseudodiaxial relationship between these protons in electron-deficient environments, consistent with a trans relationship between the benzoyloxy (or benzyloxy) and epoxide $\mathrm{C}-\mathrm{O}$ bonds rather than a cis arrangement. This conclusion is supported strongly by precedent from previous systems which crystallized well ${ }^{14}$ and the outcome of epoxideopening reactions (vide infra).

The results also appear to be consistent with the sense of diastereofacial selection reported by Curci and co-workers ${ }^{34}$ during the acetone/potassium caroate epoxidation of cyclooctenol and in our preliminary studies; dioxirane attack occurs on the more sterically open face of the alkene (assuming the solution conformer type or population is not modified significantly by the presence of the protecting group).${ }^{13}$ Hydrogen bond formation to a hydroxyl group clearly cannot play a part in controlling this reaction because the outcome is the same when the hydroxyl group is protected.

Epoxide hydrolysis was carried out under microwave conditions in most cases. We used $N$-methylimidazole as a base

(32) Yang, D.; Wong, M.-K.; Yip, Y.-C. J. Org. Chem. 1995, 60, 3887.

(33) For examples of related oxidations, see: (a) Csuk, R.; Dorr, P. Tetrahedron 1994, 50, 9983. (b) Angibeaud, P.; Defaye, J.; Gadelle, A.; Utille, J. P. Synthesis 1985, 1123. (c) Hayes, C. J.; Sherlock, A. E.; Selby, M. D. Org. Biomol. Chem. 2006, 4, 193. (d) Ochiai, M.; Ito, T.; Takahashi, H.; Nakanishi, A.; Toyonari, M.; Sueda, T.; Goto, S.; Shiro, M. J. Am. Chem. Soc. 1996, 118, 7716. (e) Arnone, A.; Bernardi, R.; Cavicchioli, M.; Resnati, G. J. Org. Chem. 1995, 60, 2314.

(34) Cicala, G.; Curci, R.; Fiorentino, M.; Laricchiuta, O. J. Org. Chem. 1982, 47, 2670. 
SCHEME 7. Epoxide-Opening Reactions
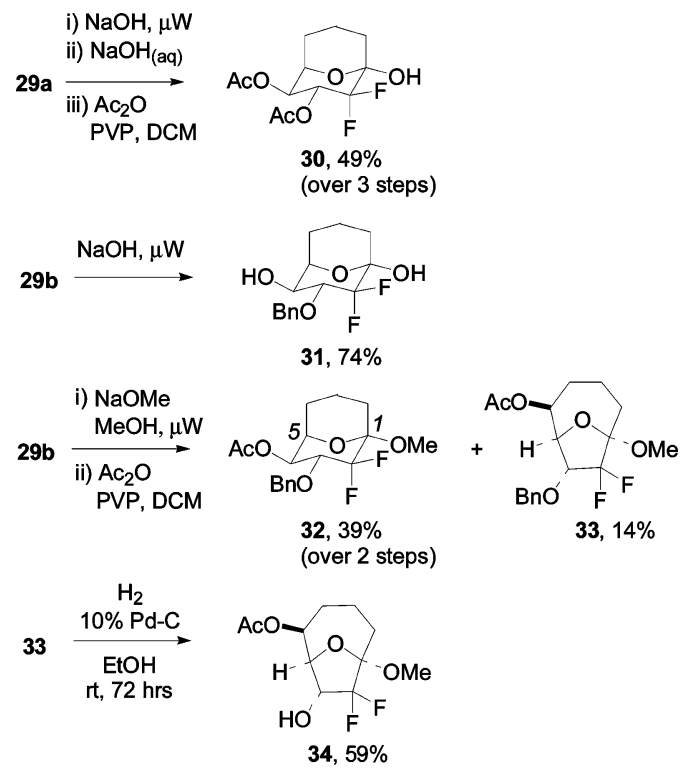

catalyst in our preliminary study ${ }^{14}$ but found subsequently that sodium hydroxide works just as well. In the case of $\mathbf{2 9 a}$, microwave irradiation in water alone consumed starting material to afford a mixture of products, which was saponified to afford a single crude triol. The crude product was then treated with an excess (5 equiv) of acetic anhydride in DCM containing poly(vinylpyridine) to afford bisacetate 30 (49\% over three steps), for which a crystal structure was obtained, confirming the stereochemistry of the ring-opened product. The pseudoanomeric hydroxyl group is expected to be the least nucleophilic in the triol and was unaffected under these neutral acetylation conditions (Scheme 7).

The hydrolysis of epoxy benzyl ether 29b was more straightforward. Treatment with a dilute $(5 \%)$ aqueous solution of $\mathrm{NaOH}$ in the microwave resulted in the formation of $\mathbf{3 1}$ in good $(74 \%)$ yield. The structure and stereochemistry of this educt also was confirmed by X-ray crystallography. We note that although the two ${ }^{3} J_{\mathrm{H}-\mathrm{F}}$ couplings visible in the ${ }^{19} \mathrm{~F}$ NMR spectrum are consistent with the presence of a pseudoaxial proton next to the $\mathrm{CF}_{2}$ center (and therefore a chair-type conformation for this ring) one of the couplings is smaller than the values reported for $\mathrm{H}-\mathrm{C}-\mathrm{C}-\mathrm{F}$ dihedrals approaching the antiperiplanar angle. These species are now highly oxygenated, which will lower ${ }^{3} J_{\mathrm{H}-\mathrm{F}}$ values generally.

The hydrolytic ring opening of the epoxide is believed to take place via initial reversible attack on the carbonyl followed by irreversible transannular epoxide opening ${ }^{35}$ with strain relief. Though the addition of nucleophiles to the carbonyl group of cyclooctanone is opposed by the development of additional transannular strain (an $I$-strain effect), the equilibrium constant for cyanohydrin formation from cyclooctanone is still as high as 1.2. ${ }^{36}$ Fluorination next to a ketonic carbonyl group favors the addition of nucleophiles, ${ }^{37}$ so there seems to be no difficulty in postulating enough of the hydroxide adduct to trigger a

(35) White, J. D.; Hrnciar, P. J. Org. Chem. 2000, 65, 9129.

(36) Eliel, E. L.; Wilen, S. H.; Mander, L. N. Stereochemistry of Organic Compounds; Wiley-Interscience: New York, 1994; p 769.

(37) Gelb, M. H.; Svaren, J. P.; Abeles, R. H. Biochemistry 1985, 24, 1813. subsequent strain-relieving reaction, ${ }^{38}$ if we assume that hydroxide addition is at least as favorable as cyanohydrin formation. The mechanism is supported strongly by the methanolysis of $\mathbf{2 9 b}$ carried out with catalytic sodium methoxide in methanol under microwave conditions. An inseparable mixture containing two products and starting material (ratio 39:10:1 by ${ }^{19} \mathrm{~F}$ NMR) was obtained, but acetylation allowed separation, to afford $\mathbf{3 2}$ and $\mathbf{3 3}$ (obtained as a mixture with $\mathbf{3 2}$ ). The presence of the methoxy group at the pseudoanomeric position in $\mathbf{3 2}$ is easily detectable in the $\mathrm{HMBC}$ spectrum by the presence of a strong ${ }^{3} J_{\mathrm{C}-\mathrm{H}}$ cross-peak between the methoxy protons and $\mathrm{C}-1$. The structure of this major product was also confirmed by the elucidation of the molecular structure in the crystal. The only credible route to major product $\mathbf{3 2}$ from $\mathbf{2 9 b}$ involves methoxide attack at the ketone carbonyl of $\mathbf{2 9 b}$ followed by transannular ring opening which confirms the sense of diastereofacial selection assigned in Scheme 6.

The formation of $\mathbf{3 3}$ was unexpected. We detected a similar ${ }^{3} J_{\mathrm{C}-\mathrm{H}}$ cross-peak between the methoxy protons and C-1 in the HMBC spectrum, which proves that direct epoxide opening by methoxide does not account for the formation of this second product. The 1D NMR spectra showed smaller ${ }^{3} J_{\mathrm{H}-\mathrm{F}}$ coupling constants than usual (the biggest one visible was $9.9 \mathrm{~Hz}$, compared to $17.5 \mathrm{~Hz}$ for 32) suggesting a nonchairlike conformation. One of the ${ }^{19} \mathrm{~F}$ NMR signals was very highly split, indicating extended or through-space couplings involving the methoxy group which appears as a doublet in the coupled spectrum and simplifies to a singlet in the $\left\{{ }^{19} \mathrm{~F}\right\}{ }^{1} \mathrm{H}$ spectrum. The structure $\mathbf{3 3}$ is assigned on the basis of this evidence; it must be formed by transannular nucleophilic ring opening of the epoxide from C-8 rather than from C-7. We were unable to grow suitable crystals of this material. Unfortunately, hydrogenolysis of the benzyl ether to afford $\mathbf{3 4}$ failed to deliver crystalline material, but the HMBC spectrum showed a much stronger $\mathrm{CH}_{3} \mathrm{O} / \mathrm{C}-1$ cross-peak. The full scope of this reaction and its mechanism will be discussed elsewhere.

Dihydroxylation of benzyl ether 20b under UpJohn conditions $^{39}$ afforded a mixture of separable diols; both afforded crystals of suitable quality for X-ray crystallographic analysis allowing the identification of the major and minor products as 37 and 38 (3:1), arising from diols $\mathbf{3 5}$ and $\mathbf{3 6}$ which undergo transannular collapse with relief of strain (Scheme 8).

We were surprised to note that the major product $\mathbf{3 7}$ arose from oxidant attack cis to the benzyloxy group. In our communication of related work, we advanced an explanation which involved delivery of the osmium reagent to the less accessible concave face of a boat-chair conformer by coordination to the Lewis basic carbonyl group oxygen. In the preliminary case, ${ }^{13}$ we were confident of the identity of the major conformer in solution; however, the ${ }^{19} \mathrm{~F}$ NMR spectra of 20a and 20b merely broaden at temperatures as low as $213 \mathrm{~K}$ preventing conformational insight.

This product is still formed under the conditions developed by Donohoe ${ }^{40}$ which involve the stoichiometric $\mathrm{OsO}_{4} \cdot$ TMEDA

(38) (a) For a computational study of the prototypical transannular reaction, see: Parveen; Singh, H.; Singh, T. V.; Bharatam, P. V.; Venugopalan, P. Theochem: J. Mol. Struct. 2004, 685, 139. For a recent elegant synthetic application of a transannular reaction, see: (b) Nicolaou, K. C.; Carenzi, G. E. A.; Jeso, V. Angew. Chem., Int. Ed. 2005, 44, 3895. (c) Park, C. M. J. Org. Chem. 2006, 71, 413. 1973.

(39) VanRheenen, V.; Kelly, R. C.; Cha, D. Y. Tetrahedron Lett. 1976,

(40) Donohoe, T. J. Synlett 2002, 1223.

1580 J. Org. Chem., Vol. 72, No. 5, 2007 
SCHEME 8. Dihydroxylation and Transannular Collapse

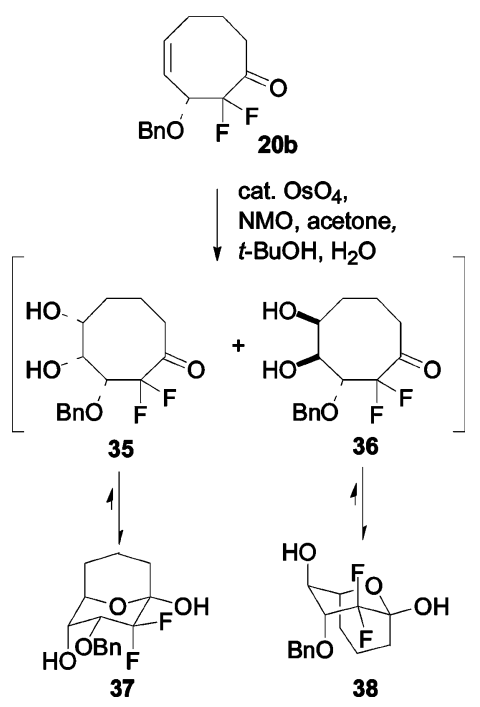

SCHEME 9. Benzyl Ether Hydrogenolyses

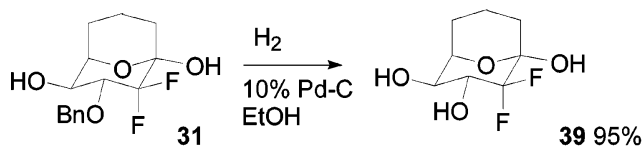

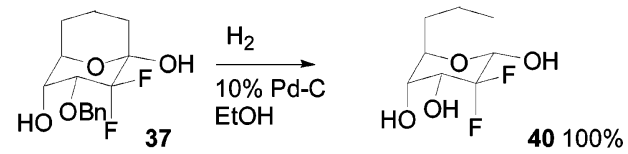

$$
\begin{aligned}
& \underbrace{\mathrm{FtOH}}_{38} \underset{\substack{10 \% \mathrm{Pd}-\mathrm{C} \\
\mathrm{BnO}}}{\mathrm{HO}}
\end{aligned}
$$

SCHEME 10. Attempted Selective Phosphorylation

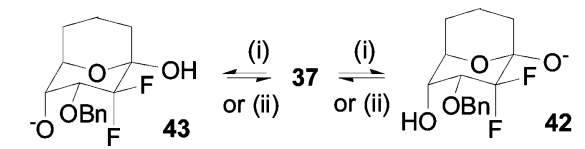

$$
\begin{aligned}
& (\mathrm{BnO})_{2} \mathrm{P}(\mathrm{O}) \mathrm{O}_{\mathrm{F}}^{\mathrm{OBn}} \mathrm{F}_{45} \mathrm{OP}(\mathrm{O})(\mathrm{OBn})_{2}+\underbrace{\mathrm{OBn}}_{\mathrm{HO}} \mathrm{F}_{\mathrm{F}} \mathrm{OP}(\mathrm{O})(\mathrm{OBn})_{2}
\end{aligned}
$$

(i) $n$-BuLi, THF, -78 to $0^{\circ} \mathrm{C}$; or,

(ii) NaHMDS, $15-$ crown-5, THF, -78 to $0^{\circ} \mathrm{C}$.

complex. In an NMR experiment, we observed an ca. 1:1 mixture of osmate esters ${ }^{41}$ before acidic methanolysis and a 1:1 mixture of $\mathbf{3 7}$ and $\mathbf{3 8}$ after workup. The presence of the chelating TMEDA ligand appears to have made the unexpected pathway less favorable but has not prevented its operation. Donohoe and co-workers have suggested that the diamine and the metal oxide appear to stay bound together under the dihydroxylation conditions, so control via coordination to the carbonyl group seems extremely unlikely under these conditions.

(41) Donohoe, T. J.; Johnson, P. D.; Pye, R. J.; Keenan, M. Org. Lett. $\mathbf{2 0 0 5}, 7,1275$. This paper describes a well-characterized cyclic osmate ester complexed to TMEDA.
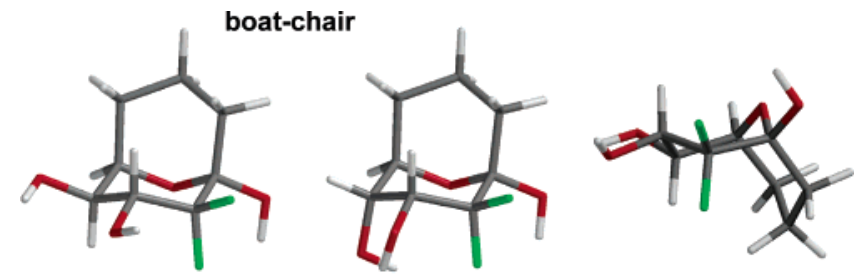

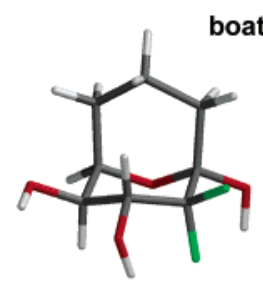

39

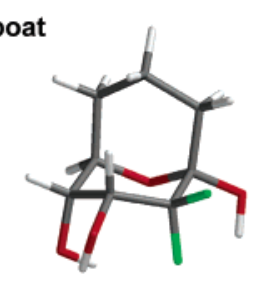

40

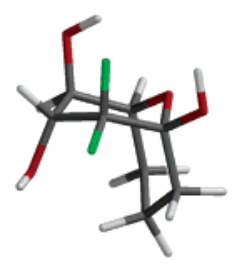

41
FIGURE 1. Calculated lowest-energy conformations for 39-41. The conformational descriptors refer to the carbon skeleton.

TABLE 1. Energies for RHF 6-31G* Optimized Structures and Calculated Energies (RHF 6-31+G**) for the Lowest-Energy Conformers of 39-41

\begin{tabular}{cccc}
\hline triol & conformer & $\begin{array}{c}E_{\text {rel }} / \mathrm{kcal} \mathrm{mol}^{-1} \\
\left(6-31 \mathrm{G}^{*}\right)\end{array}$ & $\begin{array}{c}E_{\text {rel }} / \mathrm{kcal} \mathrm{mol}^{-1} \\
\left(6-311+\mathrm{G}^{* *}\right)\end{array}$ \\
\hline $\mathbf{3 9}$ & boat-boat & 0.594 & 0.000 \\
$\mathbf{3 9}$ & boat-chair & 3.028 & 2.310 \\
$\mathbf{4 0}$ & boat-boat & 0.000 & 0.276 \\
$\mathbf{4 0}$ & boat-chair & 2.118 & 2.397 \\
$\mathbf{4 1}$ & boat-boat & 2.742 & 3.150 \\
$\mathbf{4 1}$ & boat-chair & 4.774 & 4.126 \\
\hline
\end{tabular}

We also examined the ruthenium-based dihydroxylation described recently by Tiwari and Misra ${ }^{42}$ and found it most effective with rapid conversion of $\mathbf{2 9 b}$ to the bicyclic products after a short reaction time, though with lower stereoselectivity (37/38 1.7:1) than under the UpJohn conditions. The elucidation of the controlling factors in these oxidations will require electronic structure calculations which lie outside the scope of this manuscript.

Unprotected Pentopyranose Analogues and Conformational Analysis. Diols 31, 37, and 38 were debenzylated smoothly under conventional conditions to afford triols 39-41 completing the syntheses of the first three examples of this new class of difluorinated and conformationally locked sugar analogues (Scheme 9). As drawn, 39 represents a locked 2-deoxy2,2 -difluoro analogue of the $\beta$-L-lyxo- or $\beta$-L-xylopyranoside in the ${ }^{1} \mathrm{C}_{4}$ conformation whereas $\mathbf{4 1}$ is the $\alpha$-anomer in the ${ }^{4} \mathrm{C}_{1}$ conformation. As drawn, triol $\mathbf{4 0}$ is the locked 2-deoxy-2,2difluoro analogue of $\beta$-D-arabino- or ribopyranoside.

The line formula representations of 39-41 conceal a number of close contacts between atoms which will result in Van der Waals strain, notably between $\mathbf{4 0}$ and $\mathbf{4 1}$ where there are pseudo1,3-diaxial heavy atoms.

The consequences were explored by carrying out a Monte Carlo conformational search (MMFF94 force field) in Spartan 04. ${ }^{43}$ The geometries of all the conformers generated in this way were optimized by ab initio calculations (RHF 6-31G*), and energies were calculated using the $6-311+\mathrm{G}^{* *}$ basis set. Table 1 shows the relative energies of the lowest-energy

(42) Tiwari, P.; Misra, A. K. J. Org. Chem. 2006, 71, 2911.

(43) Spartan 04, version 1.0.3, Wavefunction Inc.: 18401 Von Karman Avenue, Suite 370, Irvine, CA 92612, 2005. 


\section{SCHEME 11. Phosphorylation Following Secondary Hydroxyl Protection}

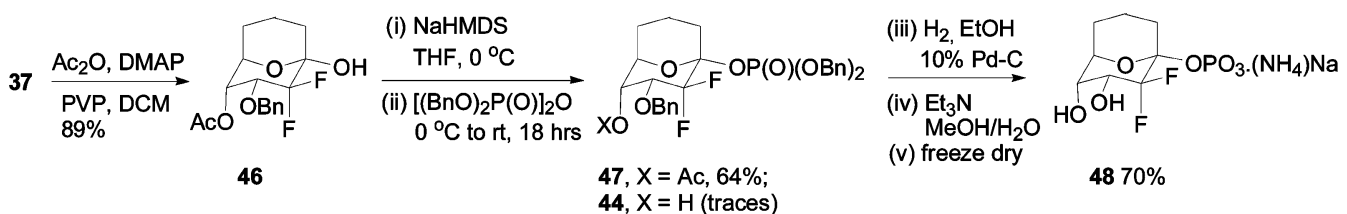

conformers; for all three sugar analogues, these have the functionalized pyran ring in a chair conformation (Figure 1).

Formally, the eight-membered carbon skeleta of the bicycles occupy oxygen-bridged boat-boat conformations in the lowestenergy conformers, and the oxygen-bridged boat-chair conformations are both ca. $2 \mathrm{kcal} \mathrm{mol}^{-1}$ higher in energy for $\mathbf{3 9}$ and 40 and ca. $1 \mathrm{kcal} \mathrm{mol}^{-1}$ higher in energy for $\mathbf{4 1}$. The boat-boat conformer brings two groups (substituents on C-3 and C-7) very close together. In 39, for example, $\mathrm{H}-3$ and an $\mathrm{H}-7$ proton are within $2.1 \AA$, but it also allows each bridging $\mathrm{C}-\mathrm{O}$ bond to be close to antiperiplanar to a $\mathrm{C}-\mathrm{H}$ and the exocyclic $\mathrm{C}-\mathrm{O}$ bond to be antiperiplanar to a $\mathrm{C}-\mathrm{C}$ bond. In the boat-chair, $\mathrm{H}-2$ and an $\mathrm{H}-7$ proton are within $2.25 \AA$, and one of the fluorine atoms is within $2.25 \AA$ of $\mathrm{H}-2$. The antiperiplanar relationships with the bridging $\mathrm{C}-\mathrm{O}$ bonds in the boat-chair are lost.

There is some distortion of structure $\mathbf{4 0}$ to allow the pseudo1,3-diaxial oxygen and fluorine atoms to relieve some Van der Waals strain. The largest ${ }^{3} J_{\mathrm{H}-\mathrm{F}}$ 's observed were for $\mathbf{4 0}$ and the intermediates leading to and derived from it; a similar value was observed for 39. These values are consistent with the calculated low-energy conformations. Though $\mathbf{4 1}$ has the potential to flip the functionalized ring into a boat and exchange the two axial hydroxyl groups into equatorial environments, the ${ }^{3} J_{\mathrm{H}-\mathrm{F}}$ suggests that the methine is equatorial and bisects the $\mathrm{F}-\mathrm{C}-\mathrm{F}$ angle, a conclusion supported by the ab initio calculations (the alternate conformer is $1 \mathrm{kcal} \mathrm{mol}^{-1}$ higher in energy).

Synthesis of a Pentopyranosyl Phosphate Analogue. Initially, phosphorylation was attempted without further protection steps. Diol 37 contains two hydroxyl groups which should differ significantly in acidity. ${ }^{44}$ Treating diol 31 with one equivalent of a strong base and allowing the system to equilibrate should favor the formation of $\mathbf{4 2}$ at the expense of $\mathbf{4 3}$. The $\mathrm{p} K_{\mathrm{a}}$ of the pseudoanomeric hydroxyl group should be lower than the secondary hydroxyl because of the combined inductive effects of the bridging oxygen and the two fluorine atoms; phosphorylation of $\mathbf{4 2}$ was therefore anticipated as the kinetic pathway (Scheme 10)..$^{45}$

Deprotonation with $n$-BuLi at $-78{ }^{\circ} \mathrm{C}$, slow warming to room temperature, and equilibration overnight, followed by the addition of tetrabenzyl pyrophosphate, afforded a mixture of $44(14 \%), 45(3 \%)$, and recovered 37 (35\%). A higher yield (43\%) of the monophosphate $\mathbf{4 4}$ could be achieved by changing the base to NaHMDS and adding Na-selective 15-crown-5, consistent with the formation of a more ionic and dissociated

(44) (a) For calculations of hemiacetal $\mathrm{p} K_{\mathrm{a}}$ (the values are only ca. $2-3$ $\mathrm{p} K_{\mathrm{a}}$ units lower than those of the analogous alcohols), see: Guthrie, J. P.; Pitchko, V. J. Am. Chem. Soc. 2000, 122, 5520. (b) An estimate used by Jencks suggests a larger difference of $5 \mathrm{p} K_{\mathrm{a}}$ units: Jencks, W. P. Catalysis in Chemistry and Enzymology; McGraw-Hill: New York, 1969; p 522.

(45) The rates of nucleophilic oxyanion attack at phosphotriesters were shown to depend linearly on nucleophile $\mathrm{p} K_{\mathrm{a}}$ with a Brönsted coefficient $\left(\beta_{\mathrm{N}}\right)$ of $0.3-0.48$ (the size depends on the leaving group). See: Khan, S. A.; Kirby, A. J. J. Chem. Soc. (B) 1970, 1172. We therefore anticipated a competition. Though $\mathbf{4 2}$ sould be the major species present, $\mathbf{4 3}$ could be as much as $2.5 \log$ units more nucleophilic than $\mathbf{4 2}$ (assuming a maximum $\beta_{\mathrm{N}}$ of 0.5$)$. This may explain the relatively low selectivity.
Na salt. However, the poor conversion of $\mathbf{3 7}$ and loss of material in $\mathbf{4 5}$ directed us toward protection of the secondary hydroxyl group. Acetylation to $\mathbf{4 6}$ occurred selectively (89\%), and the regiochemistry was confirmed by an $\mathrm{HMBC}$ experiment which shows a cross-peak $\left({ }^{3} J_{\mathrm{C}-\mathrm{H}}\right)$ between the acetate carbonyl carbon and $\mathrm{H}-4$. Exposure of $\mathbf{4 6}$ to NaHMDS followed by the addition of tetrabenzyl pyrophosphate allowed the isolation of $\mathbf{4 7}$ in good yield, though deacetylated $\mathbf{4 4}$ was an occasional contaminant after chromatography. Hydrogenolysis of the benzyl groups was followed by deacetylation, lyophilization, and column chromatography allowing the isolation of deprotected material (Scheme 11). No intermediates were purified during this sequence, but we did check for ${ }^{19} \mathrm{~F}$ and ${ }^{31} \mathrm{P}$ NMR spectral changes, obtaining accurate ion masses of the crude materials at each stage. Particularly broad (and rather uninformative) ${ }^{31} \mathrm{P}$ NMR spectra were obtained for the free phosphomonoester diacid intermediates.

The final structure $\mathbf{4 8}$ is assigned as the ammonium sodium salt on the basis of the presence of ammonia in the chromatographic eluent; chromatography over silica can lead to the formation of monosodium salts, consistent with the results of combustion analysis.

The successful development of a phosphorylation and deprotection strategy sets the stage for the preparation of a wider range of analogues and the chemical or enzymatic synthesis of the NDP sugar analogues themselves.

\section{Conclusions}

Telescoped syntheses of locked difluorinated analogues of pentopyranosides have been achieved using metalated difluoroenol acetal chemistry and RCM as key steps in high-yielding multistep sequences which contain minimal purifications. Dihydroxylation allows triol synthesis though with modest stereoselectivity in the case of the all-cis triol and subsequent bicyclic hemiacetal. The toxic osmium(VIII) reagent can be replaced by $\mathrm{Ru}$ when stereoselectivity is not an issue. Epoxidation and hydrolysis provide a highly stereoselective route to a stereocomplementary class of analogue. A viable phosphorylation strategy involving blocking of the secondary hydroxyl group followed alkoxide formation from the pseudoanomeric hydroxyl group, and subsequent phosphorylation has been developed. Conversion of the sensitive triester to the more robust monoester then allows base-catalyzed deacetylation-completing syntheses of a representative example of a new class of analogue of important biomolecules.

\section{Experimental Section}

Representative procedures only are described in this section. Full preparative and characterization details for all other compounds are in the electronic Supporting Information (SI). 2-(2'-Methoxyethoxymethoxy)-1,1,1-trifluoroethane ${ }^{21}$ and 1,1-difluoro-2-(2'-methoxy-ethoxymethoxy)-4,4-dimethyl-hepta-1,6-dien-3-ol $\mathbf{1 5}^{20}$ were prepared according to published procedures. 
3-Allyloxy-1,1-difluoro-2-(2'-methoxy-ethoxymethoxy)-hepta1,6-diene 16. A mixture of $\mathbf{1 5}(68.24 \mathrm{mmol}, 17.40 \mathrm{~g})$ and allyl bromide ( $81.90 \mathrm{mmol}, 6.87 \mathrm{~mL}$ ) was added over $1 \mathrm{~min}$ to a vigorously stirred solution of tetra- $n$-butylammonium hydrogensulfate ( $3.45 \mathrm{mmol}, 1.16 \mathrm{~g}$ ) and sodium hydroxide (488 mmol, 24.3 $\mathrm{mL}$ of a $50 \%$ aqueous solution) at $0{ }^{\circ} \mathrm{C}$. The mixture was stirred at this temperature for $30 \mathrm{~min}$, allowed to warm to room temperature, and stirred for a further $16 \mathrm{~h}$. The yellow white solution was diluted with water $(40 \mathrm{~mL})$, and the layers were separated. The aqueous phase was extracted with diethyl ether $(4 \times 100 \mathrm{~mL})$. The combined organic extracts were washed with brine $(2 \times 30 \mathrm{~mL})$, dried $\left(\mathrm{MgSO}_{4}\right)$, filtered, and concentrated under reduced pressure to afford $\mathbf{1 6}$ as a pale yellow oil ( $18.24 \mathrm{~g}, 91 \%, 100 \%$ by GC), which was used without any further purification: $R_{f}(10 \%$ diethyl ether in hexane) $0.42 ; \delta_{\mathrm{H}}\left(300 \mathrm{MHz}, \mathrm{CDCl}_{3}\right) 5.96-5.83(\mathrm{~m}, 1 \mathrm{H}), 5.81$ (ddt, $J=16.1,10.1,6.6,1 \mathrm{H}), 5.28\left(\mathrm{ddd}, J=17.2,{ }^{2} J=3.0,{ }^{4} J=1.8\right.$, $1 \mathrm{H}$ ), 5.19 (ddd, $J=10.2,{ }^{2} J=3.0,{ }^{4} J=1.2,1 \mathrm{H}$ ), $5.09-4.94$ (env., $4 \mathrm{H}), 4.10$ (ddt, $J=12.7,5.1,1.5,1 \mathrm{H}), 4.06-4.00(\mathrm{~m}, 1 \mathrm{H}), 3.94-$ $3.74(\mathrm{~m}, 3 \mathrm{H}), 3.61-3.57(\mathrm{~m}, 2 \mathrm{H}), 3.41(\mathrm{~s}, 3 \mathrm{H}), 2.13-2.06(\mathrm{~m}$, $2 \mathrm{H}), 1.95-1.70(\mathrm{~m}, 2 \mathrm{H}) ; \delta_{\mathrm{C}}\left(75 \mathrm{MHz}, \mathrm{CDCl}_{3}\right) 156.0\left(\mathrm{dd},{ }^{1} J_{\mathrm{C}-\mathrm{F}}=\right.$ $291.8,282.8), 137.7,134.3,117.3,115.1,112.4\left(\mathrm{dd},{ }^{2} J_{\mathrm{C}-\mathrm{F}}=36.8\right.$, 9.8), 97.1, 73.8, 71.6, 69.3, 68.3, 59.0, 31.0, 29.6; $\delta_{\mathrm{F}}(282 \mathrm{MHz}$, $\left.\mathrm{CDCl}_{3}\right)-97.7\left(\mathrm{dd},{ }^{2} J_{\mathrm{F}-\mathrm{F}}=63.5,{ }^{4} J_{\mathrm{F}-\mathrm{H}}=1.9,1 \mathrm{~F}\right),-109.5(\mathrm{dd}$, $\left.{ }^{2} J_{\mathrm{F}-\mathrm{F}}=63.5,{ }^{4} J_{\mathrm{F}-\mathrm{H}}=3.8,1 \mathrm{~F}\right) ; v_{\mathrm{max}}(\mathrm{film}) / \mathrm{cm}^{-1} 2880 \mathrm{~s}, 1748 \mathrm{~m}$, $1642 \mathrm{w} ; \mathrm{m} / \mathrm{z}$ (FAB) $293\left(20 \%,[\mathrm{M}+\mathrm{H}]^{+}\right) 215$ (24), 165 (74), 137 (90), 89 (100), 59 (84); HRMS (FAB, $[\mathrm{M}+\mathrm{H}]^{+}$) calcd for $\mathrm{C}_{14} \mathrm{H}_{23} \mathrm{~F}_{2} \mathrm{O}_{4}$ 293.15634, found 293.15634.

4,4-Difluoro-5-(2-methoxy-ethoxymethoxy)-deca-1,5,9-trien3-ol 17. A solution of ether $\mathbf{1 6}$ (34.25 mmol, $10.00 \mathrm{~g})$ in THF (60 $\mathrm{mL}$ ) was added dropwise over $15 \mathrm{~min}$ to a stirred solution of LDA (prepared from $n \mathrm{BuLi}(68.50 \mathrm{mmol}, 28.30 \mathrm{~mL}$ of a $2.42 \mathrm{M}$ solution in hexane) and diisopropylamine (75.30 mmol, $10.58 \mathrm{~mL})$ in THF $(342 \mathrm{~mL}))$ at $-100{ }^{\circ} \mathrm{C}$ under a nitrogen atmosphere. The pale pink solution was stirred at this temperature for $30 \mathrm{~min}$ before being allowed to warm to $-30^{\circ} \mathrm{C}$ over $4 \mathrm{~h}$ and stirred for a further $3 \mathrm{~h}$ at this temperature. The solution changed color during warming, from yellow through orange to brown and finally black. The reaction was quenched with ammonium chloride $(10 \mathrm{~mL}$ of a saturated aqueous solution), whereupon the black color disappeared and an orange/red solution was observed. The layers were separated, and the aqueous phase was extracted with diethyl ether $(3 \times 150 \mathrm{~mL})$. The combined organic extracts were washed with brine $(2 \times 50$ $\mathrm{mL})$, dried $\left(\mathrm{MgSO}_{4}\right)$, and concentrated under reduced pressure to give the homoallylic alcohol 17 (8.71 g, 95\% conversion by NMR and GC) as a red-brown oil, which was used without further purification; $R_{f}\left(30 \%\right.$ ether in hexane) $0.12 ; \delta_{\mathrm{H}}\left(300 \mathrm{MHz}, \mathrm{CDCl}_{3}\right)$ 5.93 (ddd, $J=17.2,10.5,5.6,1 \mathrm{H}), 5.80$ (ddt, $J=17.1,10.1,6.4$, $1 \mathrm{H}), 5.57(\mathrm{td}, J=7.3,1.3,1 \mathrm{H}), 5.47\left(\mathrm{dt}, J=17.2,{ }^{2} J=1.5,1 \mathrm{H}\right)$, $5.35\left(\mathrm{dt}, J=10.5,{ }^{2} J=1.5,1 \mathrm{H}\right), 5.07-4.95(\mathrm{~m}, 4 \mathrm{H}), 4.50(\mathrm{broad}$ $\mathrm{s}, 1 \mathrm{H}), 3.86(\mathrm{t}, J=4.6,1 \mathrm{H}), 3.85(\mathrm{t}, J=4.6,1 \mathrm{H}), 3.58(\mathrm{t}, J=4.6$, $2 \mathrm{H}), 3.38(\mathrm{~s}, 3 \mathrm{H}), 2.92(1 \mathrm{H}$, broad s), 2.35-2.25 (m, 2H), 2.20$2.08(\mathrm{~m}, 2 \mathrm{H}) ; \delta_{\mathrm{C}}\left(75 \mathrm{MHz}, \mathrm{CDCl}_{3}\right) 145.4\left(\mathrm{dd},{ }^{2} J_{\mathrm{C}-\mathrm{F}}=27.5\right.$, $\left.{ }^{2} J_{\mathrm{C}-\mathrm{F}}=25.2\right), 135.5,131.5,119.8\left(\mathrm{t}, J_{\mathrm{C}-\mathrm{F}}=5.4\right), 118.8,118.2$ $\left(\mathrm{dd},{ }^{1} J_{\mathrm{C}-\mathrm{F}}=250.1,{ }^{1} J_{\mathrm{C}-\mathrm{F}}=247.1\right), 115.4,97.2,72.4(\mathrm{dd}$, $\left.{ }^{2} J_{\mathrm{C}-\mathrm{F}}=30.5,{ }^{2} J_{\mathrm{C}-\mathrm{F}}=27.5\right), 70.5,67.9,58.0,32.0,23.6 ; \delta_{\mathrm{F}}(282$ $\left.\mathrm{MHz}, \mathrm{CDCl}_{3}\right)-109.5\left(\mathrm{dd},{ }^{2} J_{\mathrm{F}-\mathrm{F}}=253.2, J_{\mathrm{H}-\mathrm{F}}=8.3,1 \mathrm{~F}\right),-115.9$ $\left(\mathrm{dd},{ }^{2} J_{\mathrm{F}-\mathrm{F}}=253.5, J_{\mathrm{H}-\mathrm{F}}=14.7,1 \mathrm{~F}\right) ; v_{\max }(\mathrm{film}) / \mathrm{cm}^{-1} 3434 \mathrm{br}$, 2928w, 1682w, 1641w, 1452w, 1252w, 1170s, 1112s, 1006s, 933s; $\mathrm{m} / \mathrm{z}(\mathrm{FAB}) 293\left(44 \%,[\mathrm{M}+\mathrm{H}]^{+}\right), 137$ (100), 89 (90), 59 (100); HRMS (FAB, $\mathrm{MH}^{+}$) calcd for $\mathrm{C}_{14} \mathrm{H}_{23} \mathrm{~F}_{2} \mathrm{O}_{4}$ 293.15648, found 293.15648

3-Benzoyloxy-4,4-difluoro-5-( $2^{\prime}$-methoxy-ethoxymethoxy)deca-1,5Z,9-triene 18a. Alcohol 17 (6.3 g, $21.7 \mathrm{mmol})$, benzoic anhydride (4.90 g, $21.7 \mathrm{mmol})$, and DMAP (0.53 g, $4.3 \mathrm{mmol})$ were dissolved in DCM (217 mL). Poly(vinylpyridine) (10.6 g, 10.6 mmol, 0.5 equiv) was added, and the reaction mixture was swirled gently at room temperature overnight. The resin was collected at the pump and washed with water $(50 \mathrm{~mL})$ and saturated $\mathrm{NaHCO}_{3}$ solution $(50 \mathrm{~mL})$. The aqueous layer was extracted with diethyl ether $(3 \times 50 \mathrm{~mL})$, and the combined organic extracts were washed with brine, dried, and concentrated in vacuo to yield $\mathbf{1 8 a}$ as a brown oil $(6.85 \mathrm{~g}, 80 \%)$. The crude product was taken on without purification: $R_{f}\left(30 \%\right.$ diethyl ether in hexane) $0.27 ; \delta_{\mathrm{H}}(300 \mathrm{MHz}$, $\left.\mathrm{CDCl}_{3}\right) 8.09-8.05(\mathrm{~m}, 2 \mathrm{H}), 7.58$ (apparent $\mathrm{tt}, J=7.4,{ }^{4} \mathrm{~J}=1.4$, $1 \mathrm{H}), 7.48-7.42(\mathrm{~m}, 2 \mathrm{H}), 6.01-5.89(\mathrm{~m}, 2 \mathrm{H}), 5.73$ (ddt, $J=17.0$, $10.2,6.4,1 \mathrm{H}), 5.62(\mathrm{t}, J=7.5,1 \mathrm{H}), 5.53\left(\mathrm{dd}, J=16.0,{ }^{2} J=1.3\right.$, $1 \mathrm{H}), 5.43\left(\mathrm{dd}, J=10.3,{ }^{2} J=1.3,1 \mathrm{H}\right), 5.00(\mathrm{~s}, 2 \mathrm{H}), 5.00-4.90$ $(\mathrm{m}, 2 \mathrm{H}), 3.94-3.80(\mathrm{~m}, 2 \mathrm{H}), 3.60-3.55(\mathrm{~m}, 2 \mathrm{H}), 3.38(\mathrm{~s}, 3 \mathrm{H})$, $2.33-2.23(\mathrm{~m}, 2 \mathrm{H}), 2.13-2.04(\mathrm{~m}, 2 \mathrm{H}) ; \delta_{\mathrm{C}}\left(75 \mathrm{MHz}, \mathrm{CDCl}_{3}\right)$ $164.8,144.8\left(\mathrm{t},{ }^{2} J_{\mathrm{C}-\mathrm{F}}=25.7\right), 137.3,133.4,129.9,129.5,128.9$ $\left(\mathrm{dd}, J_{\mathrm{C}-\mathrm{F}}=3.6,1.8\right), 128.4,121.4,120.2\left(\mathrm{t}, J_{\mathrm{C}-\mathrm{F}}=5.1\right), 117.3$ $\left(\mathrm{dd},{ }^{1} J_{\mathrm{C}-\mathrm{F}}=251.2,247.4\right), 115.4,98.3,72.8\left(\mathrm{dd},{ }^{2} J_{\mathrm{C}-\mathrm{F}}=31.7\right.$, 26.9), 71.6, 68.9, 59.0, 33.9, 24.5; $\delta_{\mathrm{F}}\left(282 \mathrm{MHz}, \mathrm{CDCl}_{3}\right)-110.8$ $\left(\mathrm{dd},{ }^{2} J_{\mathrm{F}-\mathrm{F}}=253.2, J_{\mathrm{H}-\mathrm{F}}=10.9,1 \mathrm{~F}\right),-112.4\left(\mathrm{dd},{ }^{2} J_{\mathrm{F}-\mathrm{F}}=253.2\right.$, $\left.J_{\mathrm{H}-\mathrm{F}}=12.3,1 \mathrm{~F}\right) ; v_{\max }($ film $) / \mathrm{cm}^{-1} 2887 \mathrm{w}, 1730 \mathrm{~s}, 1602 \mathrm{w}, 1452 \mathrm{w}$, $1264 \mathrm{~s}, 1096 \mathrm{~s}, 988 \mathrm{~s}, 709 \mathrm{~s} ; \mathrm{m} / \mathrm{z}$ (EI) $396\left(3 \%, \mathrm{M}^{+}\right) 355$ (7), 220 (39), 205 (100), 145 (21), 106 (68); HRMS (EI, $\mathbf{M}^{+}$) calcd for $\mathrm{C}_{21} \mathrm{H}_{26} \mathrm{~F}_{2} \mathrm{O}_{5}$ 396.17473, found 396.17473.

3-Benzoyloxy-4,4-difluoro-deca-1,9-dien-5-one 19a. Thionyl chloride (15.6 mmol, $1.12 \mathrm{~mL}$ ) was added to a stirred solution of benzoate $18 \mathrm{a}(15.6 \mathrm{mmol}, 6.16 \mathrm{~g})$ in methanol $(156 \mathrm{~mL})$ at $0{ }^{\circ} \mathrm{C}$. The solution was allowed to warm to room temperature and stirred for $18 \mathrm{~h}$, and then the solvent was removed in vacuo. The resulting paste was taken up in water $(120 \mathrm{~mL})$, and the mixture was extracted with diethyl ether $(5 \times 100 \mathrm{~mL})$. The combined organic extracts were washed with $\mathrm{NaHCO}_{3}(200 \mathrm{~mL})$ and brine $(200 \mathrm{~mL})$, dried $\left(\mathrm{MgSO}_{4}\right)$, filtered, and concentrated in vacuo to give ketone 19a (100 mg, 75\%, 88\% by GC) as a brown oil, which could be used crude or purified on silica gel eluted with $10 \%$ ethyl acetate in hexane to afford a clear oil $\left(3.60 \mathrm{~g}, 75 \%, 97 \%\right.$ by GC): $R_{f}(10 \%$ diethyl ether in hexane) $0.56 ; \delta_{\mathrm{H}}\left(300 \mathrm{MHz}, \mathrm{CDCl}_{3}\right) 8.06-8.01$ $(\mathrm{m}, 2 \mathrm{H}), 7.60\left(\mathrm{tt}, J=7.5,{ }^{4} J=1.3,1 \mathrm{H}\right), 7.49-7.42(\mathrm{~m}, 2 \mathrm{H}), 6.05-$ $5.88(\mathrm{~m}, 2 \mathrm{H}), 5.71$ (ddt, $J=17.0, J=10.2, J=6.7,1 \mathrm{H}), 5.57$ $\left(\mathrm{dd}, J=16.0,{ }^{4} J=0.9,1 \mathrm{H}\right), 5.50\left(\mathrm{dd}, J=9.4,{ }^{4} J=0.9,1 \mathrm{H}\right)$, $5.02-4.94(\mathrm{~m}, 2 \mathrm{H}), 2.74(\mathrm{t}, J=7.3,2 \mathrm{H}), 2.05(\mathrm{q}, J=7.3,2 \mathrm{H})$, 1.71 (pentet, $J=7.3,2 \mathrm{H}) ; \delta_{\mathrm{C}}\left(75 \mathrm{MHz}, \mathrm{CDCl}_{3}\right) 199.7$ (dd, $\left.{ }^{2} J_{\mathrm{C}-\mathrm{F}}=28.7,28.7\right), 164.4,137.3,133.7,129.9,128.9,128.6,127.7$, $122.8,115.7,114.1\left(\mathrm{dd},{ }^{1} J_{\mathrm{C}-\mathrm{F}}=260.9256 .1\right), 72.4\left(\mathrm{dd},{ }^{2} J_{\mathrm{C}-\mathrm{F}}=\right.$ $29.9,25.1), 36.7,32.6,21.5 ; \delta_{\mathrm{F}}\left(282 \mathrm{MHz}, \mathrm{CDCl}_{3}\right)-113.7(\mathrm{dd}$, $\left.{ }^{2} J_{\mathrm{F}-\mathrm{F}}=293.9, J_{\mathrm{F}-\mathrm{H}}=9.0,1 \mathrm{~F}\right),-118.9\left(\mathrm{dd},{ }^{2} J_{\mathrm{F}-\mathrm{F}}=273.9\right.$, $\left.J_{\mathrm{F}-\mathrm{H}}=14.2,1 \mathrm{~F}\right) ; v_{\max }($ film $) / \mathrm{cm}^{-1} 3076 \mathrm{w}, 2937 \mathrm{w}, 1733 \mathrm{~s}, 1642 \mathrm{w}$; $\mathrm{m} / \mathrm{z}$ (EI) $308\left(37 \%, \mathbf{M}^{+}\right), 105$ (85); HRMS (EI, $\mathbf{M}^{+}$) calcd for $\mathrm{C}_{17} \mathrm{H}_{18} \mathrm{~F}_{2} \mathrm{O}_{3}$ 308.12242, found 308.12240.

3-Benzoyloxy-2,2-difluoro-cyclooct-4Z-en-1-one 20a. A solution of diene 19a $(4.07 \mathrm{mmol}, 1.26 \mathrm{~g})$ and $\mathrm{Ti}\left(\mathrm{O}^{i} \mathrm{Pr}\right)_{4}(1.21 \mathrm{mmol}$, $0.365 \mathrm{~mL})$ in freshly degassed DCM $(407 \mathrm{~mL})$ was refluxed under nitrogen for $30 \mathrm{~min}$, and then Grubbs' catalyst 21 (0.203 mmol, $173 \mathrm{mg}, 5 \mathrm{~mol} \%)$ was added via syringe in DCM (5 mL). Reflux was maintained until the ${ }^{19} \mathrm{~F}$ NMR spectrum of an aliquot showed that starting material had been consumed completely (after $18 \mathrm{~h}$ ). The solvent was then removed in vacuo, and the residue was taken up in diethyl ether $(30 \mathrm{~mL})$ then filtered and concentrated to give crude cyclooctenone as a brown oil which was purified by flash column chromatography (silica gel, 10\% diethyl ether in hexane) to give cyclooctenone $\mathbf{2 0 a}$ which crystallized $(0.531 \mathrm{~g}, 46 \%, 96 \%$ by GC): $R_{f}\left(10 \%\right.$ diethyl ether in hexane) $0.20 ; \mathrm{mp} 91-90{ }^{\circ} \mathrm{C} ; \delta_{\mathrm{H}}$ $\left(300 \mathrm{MHz}, \mathrm{CDCl}_{3}\right) 8.14-8.10(\mathrm{~m}, 2 \mathrm{H}), 7.64-7.58(\mathrm{~m}, 1 \mathrm{H}), 7.52-$ $7.45(\mathrm{~m}, 2 \mathrm{H}), 6.36\left(\mathrm{dddd}, J_{\mathrm{H}-\mathrm{F}}=21.3,1.5, J=7.8,{ }^{4} \mathrm{~J}=3.8\right.$, $1 \mathrm{H}), 6.07-5.96(\mathrm{~m}, 1 \mathrm{H}), 5.65(\mathrm{ddd}, J=11.0,7.8,2.5,1 \mathrm{H}), 2.82$ (dddd, $\left.{ }^{2} J=12.6, J=10.4,3.9,2.0,1 \mathrm{H}\right), 2.68\left(\mathrm{ddt},{ }^{2} J=12.6\right.$, $\left.J=7.2,{ }^{4} J=3.7,1 \mathrm{H}\right), 2.44-2.27(\mathrm{~m}, 2 \mathrm{H}), 2.13-2.02(\mathrm{~m}, 1 \mathrm{H})$, $1.89-1.74(\mathrm{~m}, 1 \mathrm{H}) ; \delta_{\mathrm{C}}\left(75 \mathrm{MHz}, \mathrm{CDCl}_{3}\right) 199.5\left(\mathrm{t},{ }^{2} J_{\mathrm{C}-\mathrm{F}}=25.5\right)$, $165.2,135.6,133.7,130.0,129.0,128.6,125.3,116.6$ (dd, $\left.{ }^{1} J_{\mathrm{C}-\mathrm{F}}=262.6,260.0\right), 68.2\left(\mathrm{dd},{ }^{2} J_{\mathrm{C}-\mathrm{F}}=24.2,18.9\right), 36.8,27.5$, $27.1 ; \delta_{\mathrm{F}}\left(282 \mathrm{MHz}, \mathrm{CDCl}_{3}\right)-111.0\left(\mathrm{~d},{ }^{2} J_{\mathrm{F}-\mathrm{F}}=239.8,1 \mathrm{~F}\right),-130.9$ $\left(\mathrm{dd},{ }^{2} J_{\mathrm{F}-\mathrm{F}}=239.8,{ }^{3} J_{\mathrm{F}-\mathrm{H}}=21.3,1 \mathrm{~F}\right) ; \nu_{\max }($ solid $) / \mathrm{cm}^{-1} 2968 \mathrm{~m}$, 2919m, 1725w, 1743w; m/z $\left(\mathrm{ES}^{+}\right) 281\left(\mathrm{M}+\mathrm{H}^{+}, 42 \%\right) 121$ (PhCOO, 100\%). Anal. calcd for $\mathrm{C}_{15} \mathrm{H}_{14} \mathrm{~F}_{2} \mathrm{O}_{3}$ : C, 64.28; H, 5.03. 
Found: C, 64.31; H, 5.16. Colorless or almost colorless material of improved quality for further use can be obtained by taking the crude oil (ca. $0.5 \mathrm{~g}, 2 \mathrm{mmol}$ ) up in a minimum volume of methanol and eluting through a preconditioned $(3 \mathrm{~mL}$ of $\mathrm{MeOH}$ per tube) thiol SPE tube with $\mathrm{MeOH}(3 \mathrm{~mL})$.

3-Benzyloxy-4,4-difluoro-5-( 2 '-methoxy-ethoxymethoxy)-deca1,5Z,9-triene 18b. A solution of $17(20.2 \mathrm{mmol}, 5.9 \mathrm{~g})$ in THF $(50 \mathrm{~mL})$ was added cautiously to a suspension of $\mathrm{NaH}(101 \mathrm{mmol}$, $4.04 \mathrm{~g}$ of a $60 \%$ suspension in mineral oil, prewashed with hexane $3 \times 30 \mathrm{~mL}$ ) in THF at $0{ }^{\circ} \mathrm{C}$ under nitrogen. The mixture was stirred at this temperature for $45 \mathrm{~min}$ as hydrogen evolved. TBAI (2.86 mmol, $1.05 \mathrm{~g})$ then benzyl bromide $(19.19 \mathrm{mmol}, 2.28 \mathrm{~mL})$ were added, and the mixture was allowed to warm to room temperature over $1 \mathrm{~h}$ and then stirred for a further $12 \mathrm{~h}$. The reaction was quenched by the cautious addition of water $(150 \mathrm{~mL})$, and the layers were separated. The aqueous layer was extracted with ethyl acetate $(3 \times 150 \mathrm{~mL})$, and the combined organic extracts were washed with brine $(100 \mathrm{~mL})$, dried $\left(\mathrm{MgSO}_{4}\right)$, and concentrated in vacuo to give benzyl ether $\mathbf{1 8 b}$ as a brown oil $(7.10 \mathrm{~g}, 92 \%, 97 \%$ by GC) which was used without further purification: $R_{f}(30 \%$ ether in hexane) $0.38 ; \delta_{\mathrm{H}}\left(400 \mathrm{MHz}, \mathrm{CDCl}_{3}\right) 7.25-7.17(\mathrm{~m}, 5 \mathrm{H}), 5.77$ (ddd, $J=17.5,10.1,7.4,1 \mathrm{H}), 5.72(\mathrm{ddt}, J=17.1,10.2,6.5,1 \mathrm{H}), 5.50$ $\left(\mathrm{td}, J=7.4,{ }^{4} J_{\mathrm{H}-\mathrm{F}}=1.4,1 \mathrm{H}\right), 5.38-5.36(\mathrm{~m}, 1 \mathrm{H}), 5.35-5.32(\mathrm{~m}$, 1H), $4.98-4.92\left(\mathrm{dq}, J=17.1,{ }^{4} J=1.7,1 \mathrm{H}\right), 4.89-4.87(\mathrm{dq}, J=$ $\left.10.2,{ }^{4} J=1.9,1 \mathrm{H}\right), 4.87\left(\mathrm{~d},{ }^{2} J=5.9\right), 4.86\left(\mathrm{~d},{ }^{2} J=5.9\right), 4.58(\mathrm{~d}$, $\left.{ }^{2} J=11.9,1 \mathrm{H}\right), 4.44\left(\mathrm{~d},{ }^{2} J=11.9,1 \mathrm{H}\right), 4.14\left(\mathrm{dddt}, J_{\mathrm{H}-\mathrm{F}}=14.2\right.$, $\left.8.5, J=7.4,{ }^{4} J=0.9\right), 3.71(\mathrm{t}, J=4.8,1 \mathrm{H}), 3.69(\mathrm{t}, J=4.4,1 \mathrm{H})$, $3.46(\mathrm{dd}, J=5.1,4.3,2 \mathrm{H}), 3.29(\mathrm{~s}, 3 \mathrm{H}), 2.26-2.18(\mathrm{~m}, 2 \mathrm{H}), 2.09-$ $2.03(\mathrm{q}, J=7.1,2 \mathrm{H}) ; \delta_{\mathrm{c}}\left(100 \mathrm{MHz}, \mathrm{CDCl}_{3}\right) 145.4\left(\mathrm{dd},{ }^{2} J_{\mathrm{C}-\mathrm{F}}=\right.$ $27.2,24.8), 137.6,137.5,131.1\left(\mathrm{dd}, J_{\mathrm{C}-\mathrm{F}}=3.6,1.8\right), 128.3,127.8$, $127.7,121.5,119.7\left(\mathrm{t}, J_{\mathrm{C}-\mathrm{F}}=5.1\right), 118.1\left(\mathrm{dd},{ }^{1} J_{\mathrm{C}-\mathrm{F}}=251.0,246.0\right)$, $115.3,98.2,79.0\left(\mathrm{dd},{ }^{2} J_{\mathrm{C}-\mathrm{F}}=31.7,25.7\right), 71.6,71.4,68.8,59.0$, $33.1,24.6 ; \delta_{\mathrm{F}}\left(282 \mathrm{MHz}, \mathrm{CDCl}_{3}\right)-108.1\left(\mathrm{dd},{ }^{2} J_{\mathrm{F}-\mathrm{F}}=254.8\right.$, $\left.J_{\mathrm{H}-\mathrm{F}}=8.5,1 \mathrm{~F}\right),-114.7\left(\mathrm{dd},{ }^{2} J_{\mathrm{F}-\mathrm{F}}=154.8, J_{\mathrm{H}-\mathrm{F}}=14.2,1 \mathrm{~F}\right)$; $v_{\max }\left(\right.$ film) $/ \mathrm{cm}^{-1} 2923 \mathrm{~s}, 1743 \mathrm{w}, 1678 \mathrm{w}, 1637 \mathrm{w}, 1454 \mathrm{~s}, 1113 \mathrm{~s}, 938 \mathrm{~s}$, $850 \mathrm{w}, 732 \mathrm{w}, 699 \mathrm{~s}$. A satisfactory mass spectrum could not be obtained for this compound (ES-MS, EI, CI, FAB).

3-Benzyloxy-4,4-difluoro-deca-1,9-dien-5-one 19b. Thionyl chloride (18.6 mmol, $1.34 \mathrm{~mL}$ ) was added to a stirred solution of enol ether $18 \mathrm{~b}(18.6 \mathrm{mmol}, 7.10 \mathrm{~g})$ in methanol $(180 \mathrm{~mL})$ at $0{ }^{\circ} \mathrm{C}$. The solution was allowed to warm to room temperature over $1 \mathrm{~h}$ and stirred for $15 \mathrm{~h}$. The methanol was removed in vacuo, and the resulting paste was taken up in water $(40 \mathrm{~mL})$ and extracted with ethyl acetate $(3 \times 150 \mathrm{~mL})$. The combined organic extracts were washed with $\mathrm{NaHCO}_{3}(70 \mathrm{~mL})$ and brine $(2 \times 100 \mathrm{~mL})$, dried $\left(\mathrm{MgSO}_{4}\right)$, and concentrated in vacuo to give ketone $19 \mathrm{~b}$ as a yellow oil $(5.13 \mathrm{~g}, 94 \%, 99 \%$ by GC) which was used in the next step without purification. The following data were obtained from a purified sample (flash chromatography, 10\% diethyl ether in hexane): $R_{f}\left(30 \%\right.$ ether in hexane) $0.68 ; \delta_{\mathrm{H}}\left(400 \mathrm{MHz}, \mathrm{CDCl}_{3}\right)$ $7.37-7.21(\mathrm{~m}, 5 \mathrm{H}), 5.85(\mathrm{ddd}, J=17.2,10.5,7.6,1 \mathrm{H}), 5.72(\mathrm{ddt}$, $J=17.1,10.2,6.7,1 \mathrm{H}), 5.53\left(\mathrm{ddd}, J=10.5,{ }^{2} J=1.4,{ }^{4} J=0.9\right.$, $1 \mathrm{H}), 5.48\left(\mathrm{dt}, J=17.2,{ }^{2} J=1.4,1 \mathrm{H}\right), 4.99\left(\mathrm{ddd}, J=17.1,{ }^{2} J=\right.$ $\left.3.4,{ }^{4} J=1.6,1 \mathrm{H}\right), 4.96\left(\mathrm{dddd}, J=10.2,{ }^{2} \mathrm{~J}=3.4,{ }^{4} \mathrm{~J}=2.0,1.2\right.$, $1 \mathrm{H}), 4.61\left(\mathrm{~d},{ }^{2} J=11.5,1 \mathrm{H}\right), 4.38\left(\mathrm{~d},{ }^{2} J=11.5,1 \mathrm{H}\right), 4.26$ (dddt, $\left.J_{\mathrm{H}-\mathrm{F}}=16.6,6.6, J=7.5,{ }^{4} J=0.9,1 \mathrm{H}\right), 2.68(\mathrm{tt}, J=7.3,1.7$, $2 \mathrm{H}$ ), 2.03 (tdd, $J=7.3,6.7,{ }^{4} J=1.2,2 \mathrm{H}$ ), 1.69 (pentet, $J=7.3$, $2 \mathrm{H}) ; \delta_{\mathrm{c}}\left(75 \mathrm{MHz}, \mathrm{CDCl}_{3}\right) 201.7\left(\mathrm{dd},{ }^{2} J_{\mathrm{C}-\mathrm{F}}=31.1,25.1\right), 137.6$, $136.8,129.6\left(\mathrm{dd}, J_{\mathrm{C}-\mathrm{F}}=3.6,1.2\right), 128.4,128.1,128.0,123.2,115.4$, $115.0\left(\mathrm{dd},{ }^{1} J_{\mathrm{C}-\mathrm{F}}=261.5,253.7\right), 79.4\left(\mathrm{dd},{ }^{2} J_{\mathrm{C}-\mathrm{F}}=30.5,23.9\right)$, 71.4, 37.6, 32.7, 21.5; $\delta_{\mathrm{F}}\left(282 \mathrm{MHz}, \mathrm{CDCl}_{3}\right)-110.6\left(\mathrm{dd},{ }^{2} J_{\mathrm{F}-\mathrm{F}}=\right.$ $\left.263.0, J_{\mathrm{H}-\mathrm{F}}=6.6,1 \mathrm{~F}\right),-124.1\left(\mathrm{dd},{ }^{1} J_{\mathrm{F}-\mathrm{F}}=263.0, J_{\mathrm{H}-\mathrm{F}}=16.6\right.$, $1 \mathrm{~F}) ; v_{\max }(\mathrm{film}) / \mathrm{cm}^{-1} 1941 \mathrm{w}, 1740 \mathrm{~s}(\mathrm{C}=\mathrm{O}), 1642 \mathrm{w}, 1455 \mathrm{w}, 1372 \mathrm{w}$, 1217s, 1091s, 913s, 736s, 698s; m/z $\left(\mathrm{CI}^{+}\right) 312\left(100 \%,\left[\mathrm{M}+\mathrm{NH}_{4}\right]^{+}\right)$ 294 (4), 216 (33), 186 (20), 170 (9), 126 (8), 108 (11), 84 (8); HRMS $\left(\mathrm{CI}^{+},\left[\mathrm{M}+\mathrm{NH}_{4}\right]^{+}\right.$) calcd for $\mathrm{C}_{17} \mathrm{H}_{24} \mathrm{~F}_{2} \mathrm{O}_{2} \mathrm{~N} 312.1770$, found 312.1769. Anal. calcd for $\mathrm{C}_{17} \mathrm{H}_{20} \mathrm{~F}_{2} \mathrm{O}_{2}$ : C, 69.37; H, 6.85. Found: C, 69.49; H, 6.98 .
3-Benzyloxy-2,2-difluoro-cyclooct-4Z-en-1-one 20b. A solution of $19 \mathrm{~b}(2.21 \mathrm{mmol}, 0.650 \mathrm{~g})$ and $\mathrm{Ti}\left(\mathrm{O}^{i} \mathrm{Pr}\right)_{4}(0.66 \mathrm{mmol}, 0.198 \mathrm{~mL})$ in freshly degassed DCM $(1000 \mathrm{~mL})$ was refluxed for 30 min under nitrogen, and then a solution of Grubbs' catalyst $21(0.11 \mathrm{mmol}$, $94 \mathrm{mg}, 5 \mathrm{~mol} \%)$ in DCM (5 mL) was added via syringe. Reflux was maintained until the ${ }^{19} \mathrm{~F}$ NMR spectrum of an aliquot showed that starting material had been consumed completely (after 18h). The solvent was removed in vacuo, and the residue was taken up in diethyl ether $(50 \mathrm{~mL})$, then filtered, and concentrated to give crude cyclooctenone $\mathbf{2 0 b}$ as a brown oil which was purified by flash column chromatography (silica gel, 10\% diethyl ether in hexane) to afford cyclooctenone $\mathbf{2 0 b}$ as a yellow solid (440 mg, $75 \%, 96 \%$ by GC): $R_{f}$ (30\% diethyl ether in hexane) $0.40 ; \mathrm{mp}$ $32-35^{\circ} \mathrm{C} ; \delta_{\mathrm{H}}\left(300 \mathrm{MHz}, \mathrm{CDCl}_{3}\right) 7.40-7.22(\mathrm{~m}, 5 \mathrm{H}), 5.93$ (app. $\mathrm{q}, J=9.2,1 \mathrm{H}), 5.60(\mathrm{ddd}, J=11.1,9.2,1.2,1 \mathrm{H}), 4.76\left(\mathrm{~d},{ }^{2} J=\right.$ $12.0,1 \mathrm{H}), 4.66\left(\mathrm{~d},{ }^{2} J=12.0,1 \mathrm{H}\right), 4.66\left(\mathrm{ddd},{ }^{3} J_{\mathrm{H}-\mathrm{F}}=20.0, J=\right.$ 8.0, 1.3, 1H), 2.60-2.48 (m, 2H), 2.28 (dddd, $J=13.7,11.1,5.6$, $3.1,1 \mathrm{H}), 2.04-1.86(\mathrm{~m}, 2 \mathrm{H}), 1.80-1.46(\mathrm{~m}, 1 \mathrm{H}) ; \delta_{\mathrm{c}}(75 \mathrm{MHz}$, $\left.\mathrm{CDCl}_{3}\right) 200.4\left(\mathrm{dd},{ }^{2} J_{\mathrm{C}-\mathrm{F}}=26.6,24.8\right), 137.0,135.4,128.6,128.1$, $128.0,127.7\left(\mathrm{~d},{ }^{3} J_{\mathrm{C}-\mathrm{F}}=6.0\right), 117.8\left(\mathrm{dd},{ }^{1} J_{\mathrm{C}-\mathrm{F}}=263.9,258.5\right)$, $173.0\left(\mathrm{dd},{ }^{2} J_{\mathrm{C}-\mathrm{F}}=23.3,19.7\right), 72.1,36.7,27.4,27.1 ; \delta_{\mathrm{F}}(376 \mathrm{MHz}$, $\left.323 \mathrm{~K}, \mathrm{CDCl}_{3}\right)-110.9\left(\mathrm{~d},{ }^{2} J_{\mathrm{F}-\mathrm{F}}=240.4,1 \mathrm{~F}\right),-130.8(\mathrm{dd}$, $\left.{ }^{2} J_{\mathrm{F}-\mathrm{F}}=240.4,{ }^{3} J_{\mathrm{H}-\mathrm{F}}=19.5,1 \mathrm{~F}\right) ; \nu_{\max }(\mathrm{solid}) / \mathrm{cm}^{-1} 2866 \mathrm{~s}, 1743 \mathrm{~s}$, $1648 \mathrm{w}, 1497 \mathrm{w}, 1455 \mathrm{~s}, 1185 \mathrm{~s}, 1100 \mathrm{~s}, 1070 \mathrm{~s}, 992 \mathrm{w}, 845 \mathrm{~s}, 812 \mathrm{~s}$, $737 \mathrm{~s}, 698 \mathrm{~s} ; \mathrm{m} / \mathrm{z}\left(\mathrm{CI}^{+}\right) 284\left(100 \%,\left[\mathrm{M}+\mathrm{NH}_{4}\right]^{+}\right) 270(5), 220(3)$, 158 (7), 140 (11), 123 (6), 90 (8); HRMS (ES ${ }^{+},\left[\mathrm{M}+\mathrm{NH}_{4}\right]^{+}$) calcd for $\mathrm{C}_{15} \mathrm{H}_{20} \mathrm{~F}_{2} \mathrm{O}_{2} \mathrm{~N}$ 284.1456, found 284.1457. Anal. calcd for $\mathrm{C}_{15} \mathrm{H}_{16} \mathrm{~F}_{2} \mathrm{O}_{2}$ : C, 67.66; H, 6.06. Found: $\mathrm{C}, 67.59 ; \mathrm{H}, 6.15$.

Carrying out the RCM with $7.12 \mathrm{mmol}$ of $19 \mathrm{~b}$ at $0.005 \mathrm{M}$ afforded 20b in $50 \%$ yield after purification. The crude material contained significant quantities of higher molecular weight material, so use of the lower concentration is therefore recommended.

$2 R^{*}$-Benzoyloxy-3,3-difluoro-9-oxa- $\left(1 S^{*}, 8 S^{*}\right)$-bicyclo[6.1.0]nonan-4-one 29a. Disodium EDTA $\left(7.2 \mathrm{~mL}\right.$ of a $4 \times 10^{-4} \mathrm{M}$ aqueous solution, $2.9 \mu \mathrm{mol})$ followed by trifluoroacetone $(3.6 \mathrm{~mL}$ of a $60 \%$ aqueous solution, $25 \mathrm{mmol}$ from a precooled syringe) was added to a solution of $20 \mathrm{a}(0.5 \mathrm{~g}, 1.8 \mathrm{mmol})$ in acetonitrile $(18 \mathrm{~mL})$ at $0{ }^{\circ} \mathrm{C}$. Sodium hydrogen carbonate $(2.3 \mathrm{~g}, 31.9 \mathrm{mmol})$ and oxone ( $5.5 \mathrm{~g}, 8.6 \mathrm{mmol})$ were added in one portion. The mixture was stirred for $6 \mathrm{~h}$ and allowed to warm to room temperature. The solids were removed by filtration and washed at the pump with DCM $(25 \mathrm{~mL})$. The aqueous phase was extracted with DCM $(3 \times$ $20 \mathrm{~mL}$ ), and the combined organic extracts and filter washings were washed with brine $(20 \mathrm{~mL})$, dried $\left(\mathrm{MgSO}_{4}\right)$, and concentrated in vacuo to yield 29a as a white solid $(0.40 \mathrm{~g}, 75 \%)$ which was used without purification: $R_{f}$ (30\% ethyl acetate in hexane) $0.22 ; \mathrm{mp}$ $75-78{ }^{\circ} \mathrm{C} ; \delta_{\mathrm{H}}\left(300 \mathrm{MHz}, \mathrm{CDCl}_{3}\right) 8.18-8.13(\mathrm{~m}, 2 \mathrm{H}), 7.62(\mathrm{dt}$, $\left.J=7.3,{ }^{4} J=1.5,1 \mathrm{H}\right), 7.49(\mathrm{t}, J=7.3,2 \mathrm{H}), 5.59\left(\mathrm{ddd}, J_{\mathrm{H}-\mathrm{F}}=\right.$ $\left.20.9, J=8.9, J_{\mathrm{H}-\mathrm{F}}=4.4,1 \mathrm{H}\right), 3.24$ (ddt, $J=8.9,4.3,{ }^{4} J=1.2$, $1 \mathrm{H}), 3.05(\mathrm{dt}, J=10.6,4.3,1 \mathrm{H}), 2.86-2.65(\mathrm{~m}, 2 \mathrm{H}), 2.49$ (dddd, $\left.{ }^{2} J=14.7, J=4.5,4.3,3.0,1 \mathrm{H}\right), 2.20-2.10(\mathrm{~m}, 1 \mathrm{H}), 2.05-1.90$ $(\mathrm{m}, 1 \mathrm{H}), 1.37$ (dddd, $\left.{ }^{2} J=14.7, J=13.6,10.6,3.4,1 \mathrm{H}\right) ; \delta_{\mathrm{C}} \mathrm{NMR}$ $\left(75 \mathrm{MHz}, \mathrm{CDCl}_{3}\right)$ 198.9, 164.0, 132.8, 129.2, 127.6, 127.6, 116.7 $\left(\mathrm{t},{ }^{1} J_{\mathrm{C}-\mathrm{F}}=260.9\right), 68.9,53.9,52.0,35.0,27.5,23.2 ; \delta_{\mathrm{F}}(282 \mathrm{MHz}$, $\left.\mathrm{CDCl}_{3}\right)-113.2\left(\mathrm{dd},{ }^{2} J_{\mathrm{F}-\mathrm{F}}=247.4, J_{\mathrm{H}-\mathrm{F}}=4.4,1 \mathrm{~F}\right),-127.3(\mathrm{dd}$ $\left.{ }^{2} J_{\mathrm{F}-\mathrm{F}}=247.4, J_{\mathrm{H}-\mathrm{F}}=20.9,1 \mathrm{~F}\right) ; v_{\max }($ solid $) / \mathrm{cm}^{-1} 2954 \mathrm{w}, 1736 \mathrm{~s}$, 1275, 1262, 1250 all m, 1081m, 1070m, 707s; m/z $\left(\mathrm{EI}^{+}\right) 296(30 \%$, $\mathrm{M}^{+}$) 224 (40), 174 (100, M - BzOH); HRMS (EI, $\mathrm{M}^{+}$) calcd for $\mathrm{C}_{15} \mathrm{H}_{14} \mathrm{~F}_{2} \mathrm{O}_{4}$ 296.08602, found 296.08601. Anal. calcd for $\mathrm{C}_{15} \mathrm{H}_{14} \mathrm{~F}_{2} \mathrm{O}_{4}$ : C, 60.8; H, 4.8. Found: C, 60.9; H, 4.8.

$2 R *$-Benzyloxy-3,3-difluoro-9-oxa- $(1 S *, 8 S *)$-bicyclo[6.1.0]nonan-4-one 29b. Prepared as for 29a, from 20b $(0.620 \mathrm{~g}, 2.33$ mmol), $\mathrm{Na}_{2}$ EDTA $\left(9.31 \mathrm{~mL}\right.$ of a $4 \times 10^{-4} \mathrm{M}$ aqueous solution), acetonitrile $(23.30 \mathrm{~mL})$, trifluoroacetone $(4.66 \mathrm{~mL}$ of a $60 \%$ aqueous solution, $25 \mathrm{mmol}), \mathrm{NaHCO}_{3}(2.94 \mathrm{~g}, 34.95 \mathrm{mmol})$, and oxone (7.16 $\mathrm{g}, 11.65 \mathrm{mmol}$ ) for $6 \mathrm{~h}$ at $0{ }^{\circ} \mathrm{C}$. Purification (flash chromatography, silica gel, $20 \%$ diethyl ether in hexane) gave epoxide $\mathbf{2 9 b}$ as a white solid (495 mg, 50\%, $98 \%$ by GC): $R_{f}(30 \%$ diethyl ether in hexane) $0.20 ; \mathrm{mp} 70-73{ }^{\circ} \mathrm{C} ; \delta_{\mathrm{H}}\left(400 \mathrm{MHz}, \mathrm{CDCl}_{3}\right) 7.44-7.29(\mathrm{~m}, 5 \mathrm{H})$, 
$4.89\left(\mathrm{~d},{ }^{2} J=11.9,1 \mathrm{H}\right), 4.85\left(\mathrm{~d},{ }^{2} J=11.9,1 \mathrm{H}\right), 3.68\left(\mathrm{ddd}, J_{\mathrm{H}-\mathrm{F}}\right.$ $=20.3, J=8.6,5.1,1 \mathrm{H}), 3.07\left(\mathrm{ddt}, J=8.6,4.3,{ }^{4} J=1.6,1 \mathrm{H}\right)$, $2.90(\mathrm{dt}, J=10.7,4.3,1 \mathrm{H}), 2.76-2.68(\mathrm{~m}, 1 \mathrm{H}), 2.48\left(\mathrm{dddd},{ }^{2} J=\right.$ $\left.13.4, J=9.2,4.1,{ }^{4} J=2.2,1 \mathrm{H}\right), 2.36\left(\mathrm{dtd}, J=14.7,4.5,{ }^{2} J=\right.$ $3.1,1 \mathrm{H}), 2.09-1.99(\mathrm{~m}, 1 \mathrm{H}), 1.97-1.85(\mathrm{~m}, 1 \mathrm{H}), 1.02$ (dddd, $J=$ $14.5,13.7,10.6,3.3,1 \mathrm{H}) ; \delta_{\mathrm{c}}\left(75 \mathrm{MHz}, \mathrm{CDCl}_{3}\right) 201.1\left(\mathrm{t}, J_{\mathrm{C}-\mathrm{F}}=\right.$ $25.7), 136.8,128.5,128.2,128.1,115.6\left(\mathrm{dd},{ }^{1} J_{\mathrm{C}-\mathrm{F}}=161.5,157.9\right)$, $75.3\left(\mathrm{dd},{ }^{2} J_{\mathrm{C}-\mathrm{F}}=22.4,18.7\right), 73.2\left(\mathrm{~d},{ }^{4} J_{\mathrm{C}-\mathrm{F}}=1.2\right), 54.6\left(\mathrm{~d}, J_{\mathrm{C}-\mathrm{F}}\right.$ $=10.8), 53.8,35.8,28.3,24.0 ; \delta_{\mathrm{F}}\left(282 \mathrm{MHz}, \mathrm{CDCl}_{3}\right)-113.6(\mathrm{~d}$, $\left.{ }^{2} J_{\mathrm{F}-\mathrm{F}}=245.9,1 \mathrm{~F}\right),-128.8\left(\mathrm{dd},{ }^{2} J_{\mathrm{F}-\mathrm{F}}=245.9, J_{\mathrm{H}-\mathrm{F}}=20.3,1 \mathrm{~F}\right)$; $v_{\max }($ solid $) / \mathrm{cm}^{-1} 3465 \mathrm{w}, 2923 \mathrm{w}, 1744 \mathrm{~s}, 1499 \mathrm{w}, 1452 \mathrm{~s}, 1340 \mathrm{w}$, $1236 \mathrm{w}, 1193 \mathrm{~s}, 1105 \mathrm{~s}, 1083 \mathrm{~s}, 1019 \mathrm{~s}, 1028 \mathrm{~s}, 969 \mathrm{~s}, 862 \mathrm{~s}, 830 \mathrm{~s}, 755 \mathrm{~s}$, 702s; m/z $\left(\mathrm{CI}^{+}\right) 300\left(100 \%,\left[\mathrm{M}+\mathrm{NH}_{4}\right]^{+}\right) 282$ (6), 262 (2), 174 (3), 125 (3), 108 (3); HRMS $\left(\mathrm{ES}^{+},\left[\mathrm{M}+\mathrm{NH}_{4}\right]^{+}\right.$) calcd for $\mathrm{C}_{15} \mathrm{H}_{20} \mathrm{~F}_{2} \mathrm{O}_{3} \mathrm{~N}$ 300.1406, found 300.1409. Anal. calcd for $\mathrm{C}_{15} \mathrm{H}_{16} \mathrm{~F}_{2} \mathrm{O}_{3}$ : C, 63.82; H, 5.71. Found: C, 63.77; H, 5.78.

$3 R^{*}$-Benzyloxy-2,2-difluoro-9-oxa- $1 S *, 5 R^{*}$-bicyclo[3.3.1]nona$\mathbf{1 S}, \mathbf{4} \boldsymbol{R} *$-diol 31. Epoxide $\mathbf{2 9 b}(0.44 \mathrm{mmol}, 125 \mathrm{mg})$ and $\mathrm{NaOH}$ ( $2.2 \mathrm{~mL}$ of a $0.5 \%$ aqueous solution, $0.28 \mathrm{mmol}$ ) were sealed in a microwave vial containing a stirrer bead. The solution was irradiated in the cavity of a CEM Discover instrument $(30 \mathrm{~W}$ power to maintain a temperature of $100{ }^{\circ} \mathrm{C}$ for $10 \mathrm{~min}$, with a 10 min heating ramp, no cooling). The vial was vented and opened, and the solution was made just acidic ( $\mathrm{pH} 6$ to indicator paper) by the addition of a few drops of $\mathrm{HC} 1(0.3 \mathrm{~mL}$ of a $3 \mathrm{M}$ aqueous solution), which caused a white solid to precipitate. The aqueous solution was extracted with ethyl acetate $(3 \times 20 \mathrm{~mL})$, and the combined organic extracts were washed with $\mathrm{NaHCO}_{3}(20 \mathrm{~mL})$ and brine $(30 \mathrm{~mL})$, dried $\left(\mathrm{MgSO}_{4}\right)$, and then filtered. The solvent was removed in vacuo to give a white solid which was purified (flash silica, 50\% ethyl acetate in hexane) to give $\mathbf{3 1}$ as a white solid (98 $\mathrm{mg}, 74 \%): R_{f}$ (50\% ethyl acetate in hexane) $0.28 ; \mathrm{mp} 127-130{ }^{\circ} \mathrm{C} ; \delta_{\mathrm{H}}(300 \mathrm{MHz}$, $\left.\mathrm{CDCl}_{3}\right) 7.45-7.32(\mathrm{~m}, 5 \mathrm{H}), 5.01\left(\mathrm{dd},{ }^{2} J=11.3,{ }^{4} \mathrm{~J}=1.1,1 \mathrm{H}\right)$, $4.67\left(\mathrm{~d},{ }^{2} J=11.3,1 \mathrm{H}\right), 4.22(\mathrm{t}, J=5.1,1 \mathrm{H}), 4.06-3.98(\mathrm{~m}, 2 \mathrm{H})$, $3.39(\mathrm{~d}, J=5.4,1 \mathrm{H}), 2.23$ (br. s, $1 \mathrm{H}), 2.11-2.02(\mathrm{~m}, 1 \mathrm{H}), 1.95-$ $1.52(\mathrm{~m}, 5 \mathrm{H}) ; \delta_{\mathrm{C}}\left(75 \mathrm{MHz}, \mathrm{CD}_{3} \mathrm{OD}\right) 138.0,127.9,127.8,127.4$, $118.7\left(\mathrm{dd},{ }^{1} J_{\mathrm{C}-\mathrm{F}}=257.6,252.8\right), 93.6\left(\mathrm{dd},{ }^{2} J_{\mathrm{C}-\mathrm{F}}=26.9,20.3\right)$, $80.2\left(\mathrm{dd},{ }^{2} J_{\mathrm{C}-\mathrm{F}}=19.1,19.1\right), 74.4\left(\mathrm{~d},{ }^{4} J_{\mathrm{C}-\mathrm{F}}=2.4\right), 73.0,71.4(\mathrm{~d}$, $\left.{ }^{3} J_{\mathrm{C}-\mathrm{F}}=8.4\right), 28.7\left(\mathrm{~d},{ }^{3} J_{\mathrm{C}-\mathrm{F}}=2.4\right), 20.0,17.9 ; \delta_{\mathrm{F}}\left(282 \mathrm{MHz}, \mathrm{CD}_{3}\right.$ OD) $-115.8\left(\mathrm{dd},{ }^{2} J_{\mathrm{F}-\mathrm{F}}=247.8, J_{\mathrm{H}-\mathrm{F}}=7.6,1 \mathrm{~F}\right),(-128.7)-$ $(-129.8)\left(\mathrm{m}\right.$, incl. app. d, $\left.{ }^{2} J_{\mathrm{F}-\mathrm{F}}=247.8,1 \mathrm{~F}\right) ; v_{\max }($ solid $) / \mathrm{cm}^{-1}$ $3364 \mathrm{br}, 2949 \mathrm{w}, 1350 \mathrm{w}, 1213,1080 \mathrm{~s}, 1022 \mathrm{~s}, 907 \mathrm{~s}, 735 \mathrm{~s}, 695 \mathrm{~s} ; \mathrm{m} / \mathrm{z}$ $\left(\mathrm{CI}^{+}\right) 318\left(100 \%,\left[\mathrm{M}+\mathrm{NH}_{4}\right]^{+}\right) 228(3), 210(3), 108(10), 91$ (5), 52 (52); HRMS $\left(\mathrm{ES}^{+},\left[\mathrm{M}+\mathrm{NH}_{4}\right]^{+}\right.$) calcd for $\mathrm{C}_{15} \mathrm{H}_{22} \mathrm{~F}_{2} \mathrm{O}_{4} \mathrm{~N}$ 318.1511, found 318.1510. Anal. calcd for $\mathrm{C}_{15} \mathrm{H}_{18} \mathrm{~F}_{2} \mathrm{O}_{4}$ : C, 59.99; H, 6.04. Found: C, 60.13; H, 6.10.

Crystal data: $\mathrm{C}_{15} \mathrm{H}_{18} \mathrm{~F}_{2} \mathrm{O}_{4}$, crystal size $0.19 \times 0.10 \times 0.04 \mathrm{~mm}^{3}$, $M=300.29$, triclinic, $a=9.9359(15) \AA, b=11.1641(17) \AA, c=$ 13.130(2) $\AA, \alpha=78.181(3)^{\circ}, \beta=86.925(3)^{\circ}, \gamma=88.750(3)^{\circ}$, $U=1423.4(4) \AA{ }^{3} T=150(2) \mathrm{K}$, space group $P 1, Z=4, \mu(\mathrm{Mo}$ $\mathrm{K} \alpha)=0.117 \mathrm{~mm}^{-1}, 10395$ reflections measured, $4966[\mathrm{R}(\mathrm{int})=$ $0.0818]$ which were used in all calculations. Final $\mathrm{R}$ indices $\left[F^{2}>\right.$ $\left.2 \sigma\left(F^{2}\right)\right] \mathrm{R} 1=0.0571, \mathrm{wR} 2=0.0924 ; \mathrm{R}$ indices (all data) $\mathrm{R} 1=$ $0.1002, \mathrm{wR} 2=0.1055$.

$4 R *$-Acetoxy-3R*-benzyloxy-2,2-difluoro-1 $S^{*}$-methoxy-9-oxa$1 S^{*}, 5 R^{*}$-bicyclo[3.3.1] nonane 32 and $5 S^{*}$-Acetoxy-3R*-benzyloxy-2,2-difluoro- $1 S *$-methoxy-9-oxa- $1 S *, 4 R *$-bicyclo[4.2.1]nonane 33. A solution of epoxide $29 \mathbf{b}(0.32 \mathrm{mmol}, 90 \mathrm{mg})$ in methanolic sodium methoxide $(3.2 \mathrm{~mL}$ of a $0.1 \mathrm{M}$ solution in methanol) was irradiated in the microwave as for the hydrolysis of 29b (30 W, $100{ }^{\circ} \mathrm{C}$ for $20 \mathrm{~min}, 10 \mathrm{~min}$ heating ramp, no cooling). The solvent was removed in vacuo, and the residue was taken up in DCM $(70 \mathrm{~mL})$ and washed with cold $\mathrm{HCl}(10 \mathrm{~mL}$ of a $1 \mathrm{M}$ solution) and brine $(20 \mathrm{~mL})$, dried $\left(\mathrm{MgSO}_{4}\right)$, then filtered. Poly(vinylpyridine) $(340 \mathrm{mg}$ ) and acetic anhydride (1.17 mmol, 0.160 $\mathrm{mL}$ ) were added to the filtrate, and the mixture was swirled at room temperature for $64 \mathrm{~h}$. The poly(vinylpyridine) was removed by filtration and washed with DCM $(70 \mathrm{~mL})$. The combined organic extracts and washings were washed with $\mathrm{NaHCO}_{3}(10 \mathrm{~mL})$, brine
(20 mL), dried $\left(\mathrm{MgSO}_{4}\right)$, filtered, and concentrated in vacuo to give a gray paste which was purified (flash chromatography, silica, 20\% ethyl acetate in hexane) to give (in order of elution) $\mathbf{3 3}$ as a gray paste $\left(20 \mathrm{mg}\right.$, ca. $18 \%, 83 \%$ of a mixture with 32 by ${ }^{19} \mathrm{~F}$ NMR) followed by 32. 33: $R_{f}(20 \%$ ethyl acetate in hexane $) 0.30 ; \delta_{\mathrm{H}}(400$ $\left.\mathrm{MHz}, \mathrm{CDCl}_{3}\right) 7.38-7.30(\mathrm{~m}, 5 \mathrm{H}), 5.15(\mathrm{dd}, J=5.7,5.3,1 \mathrm{H})$, $4.84\left(\mathrm{~d},{ }^{2} J=11.9,1 \mathrm{H}\right), 4.57\left(\mathrm{~d},{ }^{2} J=11.9,1 \mathrm{H}\right), 4.42-4.38(\mathrm{~m}$, $1 \mathrm{H}), 4.33\left(\mathrm{ddd}, J_{\mathrm{H}-\mathrm{F}}=9.9,8.5, J=3.7,1 \mathrm{H}\right), 3.49\left(\mathrm{~d},{ }^{5} J_{\mathrm{H}-\mathrm{F}}=\right.$ $1.8,3 \mathrm{H}), 2.11-1.96(\mathrm{~m}, 2 \mathrm{H}), 1.92(\mathrm{~s}, 3 \mathrm{H}), 1.70-1.28(\mathrm{~m}, 4 \mathrm{H}) ; \delta_{\mathrm{C}}$ $\left(100 \mathrm{MHz}, \mathrm{CDCl}_{3}\right)$ 169.6, 136.9, 128.5, 128.1, 128.1, 123.7 (dd, $\left.{ }^{1} J_{\mathrm{C}-\mathrm{F}}=267.2,261.6\right), 105.8\left(\mathrm{dd},{ }^{2} J_{\mathrm{C}-\mathrm{F}}=29.2,18.0\right), 77.9(\mathrm{~d}$, $\left.J_{\mathrm{C}-\mathrm{F}}=9.6\right), 77.3\left(\mathrm{dd},{ }^{2} J_{\mathrm{C}-\mathrm{F}}=16.0,10.4\right), 72.4\left(\mathrm{~d},{ }^{4} J_{\mathrm{C}-\mathrm{F}}=2.4\right)$, $71.0,51.8\left(\mathrm{~d},{ }^{4} J_{\mathrm{C}-\mathrm{F}}=5.6\right), 34.3,30.1,20.9,18.0 ; \delta_{\mathrm{F}}(376 \mathrm{MHz}$, $\left.\mathrm{CDCl}_{3}\right)-114.3\left(\mathrm{dd},{ }^{2} J_{\mathrm{F}-\mathrm{F}}=235.0, J_{\mathrm{H}-\mathrm{F}}=9.9,1 \mathrm{~F}\right),(-126.0)-$ $(-126.9)\left(\mathrm{m}\right.$ incl. apparent $\left.\mathrm{d},{ }^{2} J_{\mathrm{F}-\mathrm{F}}=235.0,1 \mathrm{~F}\right) ; v_{\max }($ film $) / \mathrm{cm}^{-1}$ 2948s, 2359s, 1742s, 1454m, 1372m, 1238s, 1062s, 739w, 699w; $\mathrm{m} / \mathrm{z}\left(\mathrm{CI}^{+}\right) 374\left(100 \%,\left[\mathrm{M}+\mathrm{NH}_{4}\right]^{+}\right) 284(5), 208(6), 106$ (9), 77 (18), 52 (79); HRMS $\left(\mathrm{ES}^{+},\left[\mathrm{M}+\mathrm{NH}_{4}\right]^{+}\right.$) calcd for $\mathrm{C}_{18} \mathrm{H}_{26} \mathrm{~F}_{2} \mathrm{O}_{5} \mathrm{~N}$ 374.1774, found 374.1773. In the $\left\{{ }^{19} \mathrm{~F}\right\}^{1} \mathrm{H}$ NMR spectrum, the signal at $4.42-4.38$ simplified to $4.40(\mathrm{dd}, J=6.5,4.0,1 \mathrm{H})$ and the signal at 3.49 simplified to 3.49 (s, 3H). 32 (45 mg, 39\%): $R_{f}$ (20\% ethyl acetate in hexane) $0.16 ; \mathrm{mp} 92-93{ }^{\circ} \mathrm{C} ; \delta_{\mathrm{H}}(400 \mathrm{MHz}$, $\left.\mathrm{CDCl}_{3}\right) 7.41-7.32(\mathrm{~m}, 5 \mathrm{H}), 5.21$ (ddd, $\left.J=9.9,6.5,1.2,1 \mathrm{H}\right), 4.96$ $\left(\mathrm{d},{ }^{2} J=12.0,1 \mathrm{H}\right), 4.70\left(\mathrm{~d},{ }^{2} J=12.0,1 \mathrm{H}\right), 4.46-4.42(\mathrm{~m}, 1 \mathrm{H})$, $4.16\left(\mathrm{ddd}, J_{\mathrm{H}-\mathrm{F}}=17.4,7.6, J=9.9,1 \mathrm{H}\right), 3.51\left(\mathrm{~d},{ }^{5} J_{\mathrm{H}-\mathrm{F}}=1.5\right.$, $3 \mathrm{H}), 2.02(\mathrm{~s}, 3 \mathrm{H}), 1.96-1.60(\mathrm{~m}, 6 \mathrm{H}) ; \delta_{\mathrm{C}}\left(100 \mathrm{MHz}, \mathrm{CDCl}_{3}\right) 169.5$, 137.4, 128.4, 128.4, 128.0, $119.2\left(\mathrm{dd},{ }^{1} J_{\mathrm{C}-\mathrm{F}}=259.2,257.6\right), 95.8$ $\left(\mathrm{dd},{ }^{2} J_{\mathrm{C}-\mathrm{F}}=25.6,17.6\right), 77.2\left(\mathrm{dd},{ }^{2} J_{\mathrm{C}-\mathrm{F}}=21.6,19.2\right), 74.1(\mathrm{~d}$, $\left.{ }^{4} J_{\mathrm{C}-\mathrm{F}}=2.4\right), 72.5\left(\mathrm{~d}, J_{\mathrm{C}-\mathrm{F}}=8.8\right), 69.6,50.7\left(\mathrm{~d},{ }^{4} J_{\mathrm{C}-\mathrm{F}}=4.0\right)$, $25.9\left(\mathrm{~d}, J_{\mathrm{C}-\mathrm{F}}=2.4\right), 21.1,20.7,18.1 ; \delta_{\mathrm{F}}\left(376 \mathrm{MHz} \mathrm{CDCl}_{3}\right)-114.8$ $\left(\mathrm{dd},{ }^{2} J_{\mathrm{F}-\mathrm{F}}=248.3, J_{\mathrm{H}-\mathrm{F}}=7.1\right),-128.0\left(\mathrm{dddq},{ }^{2} J_{\mathrm{F}-\mathrm{F}}=248.3\right.$, $\left.J_{\mathrm{H}-\mathrm{F}}=17.5, J=3.8,{ }^{5} J_{\mathrm{H}-\mathrm{F}}=1.4,1 \mathrm{~F}\right) ; v_{\max }(\mathrm{solid}) / \mathrm{cm}^{-1} 2955 \mathrm{w}$, $1737 \mathrm{~s}, 1440 \mathrm{w}, 1363 \mathrm{~s}, 1239 \mathrm{~s}, 1029 \mathrm{~s}, 892 \mathrm{~s}, 758 \mathrm{~s} ; \mathrm{m} / \mathrm{z}\left(\mathrm{CI}^{+}\right) 374$ $\left(100 \%,\left[\mathrm{M}+\mathrm{NH}_{4}\right]^{+}\right) 284$ (13), 208 (9), 108 (21), 77 (19); HRMS $\left(\mathrm{ES}^{+},\left[\mathrm{M}+\mathrm{NH}_{4}\right]^{+}\right.$) calcd for $\mathrm{C}_{18} \mathrm{H}_{26} \mathrm{~F}_{2} \mathrm{O}_{5} \mathrm{~N}$ 374.1774, found 374.1777. Anal. calcd for $\mathrm{C}_{18} \mathrm{H}_{22} \mathrm{~F}_{2} \mathrm{O}_{5}$ : C, 60.67; H, 6.22. Found, $\mathrm{C}, 60.76 ; \mathrm{H}, 6.30$. In the $\left\{{ }^{19} \mathrm{~F}\right\}^{1} \mathrm{H}$ NMR spectrum, the signal at 3.51 simplified to $3.51(\mathrm{~s}, 3 \mathrm{H})$.

Crystal data: $\mathrm{C}_{18} \mathrm{H}_{22} \mathrm{~F}_{2} \mathrm{O}_{5}$, crystal size $0.35 \times 0.24 \times 0.20 \mathrm{~mm}^{3}$, $M=356.36$, triclinic, $a=7.240(2) \AA, b=9.607(3) \AA, c=13.226-$ (4) $\AA, \alpha=98.732(5)^{\circ}, \beta=102.590(5)^{\circ}, \gamma=100.713(5)^{\circ}, U=$ 864.2(4) $\AA^{3}, T=150(2) \mathrm{K}$, space group $P 1, Z=2, \mu(\mathrm{Mo} \mathrm{K} \alpha)=$ $0.113 \mathrm{~mm}^{-1}, 6306$ reflections measured, $3024[\mathrm{R}(\mathrm{int})=0.0485]$ which were used in all calculations. Final $\mathrm{R}$ indices $\left[F^{2}>2 \sigma\left(\mathrm{F}^{2}\right)\right]$ $\mathrm{R} 1=0.0455, \mathrm{wR} 2=0.1179 ; \mathrm{R}$ indices (all data) $\mathrm{R} 1=0.0554$, $\mathrm{wR} 2=0.1240$.

$5 S^{*}$-Acetoxy-2,2-difluoro-1 $S^{*}$-methoxy-9-oxa- $1 S^{*}, 4 R^{*}$-bicyclo[4.2.1]nonan-3R*-ol 34. Acetate $33(0.07 \mathrm{mmol}, 25 \mathrm{mg})$ was dissolved in ethanol ( $1 \mathrm{~mL}$ ) containing $10 \%$ palladium on activated carbon $(10 \mathrm{mg})$. The atmosphere was removed and replaced with hydrogen from a balloon. The solution was stirred at room temperature for $72 \mathrm{~h}$, and then the hydrogen atmosphere was removed and replaced with air. The solution was filtered through celite, then concentrated in vacuo, and purified by flash chromatography (silica gel, 10-30\% ethyl acetate/hexane) to give alcohol 34 as a gray paste $(10 \mathrm{mg}, 59 \%): R_{f}(30 \%$ ethyl acetate/hexane) $0.25 ; v_{\max }(\mathrm{film}) / \mathrm{cm}^{-1} 3447 \mathrm{br}, 2952 \mathrm{w}, 1736 \mathrm{~s}, 1441 \mathrm{w}, 1374 \mathrm{w}, 1232 \mathrm{~s}$, $1036 \mathrm{~s}, 973 \mathrm{w}, 787 \mathrm{w} ; \delta_{\mathrm{H}}\left(400 \mathrm{MHz}, \mathrm{CDCl}_{3}\right) 5.20-5.15(\mathrm{~m}, 1 \mathrm{H})$, $4.54\left(\mathrm{ddd},{ }^{3} J_{\mathrm{H}-\mathrm{F}}=11.0,8.1, J=3.5,1 \mathrm{H}\right), 4.32(\mathrm{ddd}, J=6.4,3.5$, $\left.{ }^{4} J_{\mathrm{H}-\mathrm{F}}=1.7,1 \mathrm{H}\right), 3.49\left(\mathrm{~d},{ }^{5} J_{\mathrm{H}-\mathrm{F}}=1.4,3 \mathrm{H}\right), 2.12-1.94(\mathrm{env} ., 6 \mathrm{H})$, $1.74-1.60(\mathrm{~m}, 3 \mathrm{H}) ; \delta_{\mathrm{C}}\left(100 \mathrm{MHz}, \mathrm{CDCl}_{3}\right) 170.0,122.8(\mathrm{t}$, $\left.{ }^{1} J_{\mathrm{C}-\mathrm{F}}=262.8\right), 105.5\left(\mathrm{dd},{ }^{2} J_{\mathrm{C}-\mathrm{F}}=28.8,18.4\right), 80.0\left(\mathrm{~d},{ }^{3} J_{\mathrm{C}-\mathrm{F}}=\right.$ 9.6), $72.0\left(\mathrm{dd},{ }^{2} J_{\mathrm{C}-\mathrm{F}}=28.0,17.6\right), 71.2,51.6\left(\mathrm{~d},{ }^{4} J_{\mathrm{C}-\mathrm{F}}=4.8\right)$, $33.7-33.6(\mathrm{~m}), 29.75-29.70(\mathrm{~m}), 21.0,18.1 ; \delta_{\mathrm{F}}\left(376 \mathrm{MHz}, \mathrm{CDCl}_{3}\right)$ $-119.6\left(\mathrm{dd},{ }^{2} J_{\mathrm{F}-\mathrm{F}}=236.5,{ }^{3} J_{\mathrm{H}-\mathrm{F}}=11.1,1 \mathrm{~F}\right),(-126.6)-(-127.5)$ (m, incl. app. d, $\left.{ }^{2} J_{\mathrm{F}-\mathrm{F}}=236.5,1 \mathrm{~F}\right) ; \mathrm{m} / \mathrm{z}\left(\mathrm{ES}^{+}\right) 289(33 \%,[\mathrm{M}+$ $\mathrm{Na}^{+}$) 155 (5), 136 (6), 73 (22), 51 (100); HRMS (ES ${ }^{+},[\mathrm{M}+$ $\left.\mathrm{NH}_{4}\right]^{+}$) calcd for $\mathrm{C}_{11} \mathrm{H}_{20} \mathrm{~F}_{2} \mathrm{O}_{5} \mathrm{~N} 374.1774$, found 374.1778. In the $\left\{{ }^{19} \mathrm{~F}\right\}{ }^{1} \mathrm{H}$ NMR spectrum, the signal at 4.32 collapses to 4.32 (dd, 
$J=6.4,3.5,1 \mathrm{H})$ and the signal at $3.49-3.49(\mathrm{~s}, 3 \mathrm{H})$. The signals reported as multiplets in the ${ }^{13} \mathrm{C}$ NMR spectrum are weak and significantly broadened.

$3 R^{*}$-Benzyloxy-2,2-difluoro-9-oxa- $1 S^{*}, 5 R^{*}$-bicyclo[3.3.1] nona$1 S^{*}, 4 S^{*}$-diol 37 and $3 R^{*}$-Benzyloxy-2,2-difluoro-9-oxa- $1 R^{*}, 5 S^{*}$ bicyclo[3.3.1]nona-1 $\boldsymbol{R}^{*}, \mathbf{4} \boldsymbol{R}^{*}$-diol 38. NMO (295 mg, $\left.2.52 \mathrm{mmol}\right)$ was added to a solution of cyclooctenone $20 \mathrm{~b}$ (336 mg, $1.26 \mathrm{mmol})$ in acetone $(3.16 \mathrm{~mL})$ and $\mathrm{H}_{2} \mathrm{O}(1.58 \mathrm{~mL})$ at $0{ }^{\circ} \mathrm{C}$. Osmium tetroxide $(0.790 \mathrm{~mL}$ of a $2.5 \%$ by wt. solution in $t-\mathrm{BuOH}, 0.063 \mathrm{mmol})$ was added, and the black solution was stirred at $0{ }^{\circ} \mathrm{C}$ for $6 \mathrm{~h}$. Solid $\mathrm{Na}_{2} \mathrm{SO}_{3}(0.4 \mathrm{~g})$ was added, and the suspension was stirred for $1 \mathrm{~h}$, then diluted with water $(3 \mathrm{~mL})$ and extracted with ethyl acetate $(3 \times 30 \mathrm{~mL})$. The combined organic extracts were washed with brine $(30 \mathrm{~mL})$, dried $\left(\mathrm{MgSO}_{4}\right)$, filtered, and concentrated in vacuo. Flash chromatography (silica gel, 50-70\% ethyl acetate in hexane) gave (in order of elution) minor diastereoisomer 38 (44 mg, 12\%) followed by a mixture of $\mathbf{3 7}$ and $\mathbf{3 8}(106 \mathrm{mg}, 28 \%)$ and then $\mathbf{3 7}$ as a white solid. 38: $R_{f}(50 \%$ ethyl acetate in hexane) $0.24 ; \mathrm{mp} 128-$ $131{ }^{\circ} \mathrm{C} ; \delta_{\mathrm{H}}\left(300 \mathrm{MHz}, \mathrm{CDCl}_{3}\right) 7.40-7.29(\mathrm{~m}, 5 \mathrm{H}), 4.89\left(\mathrm{~d},{ }^{2} J=\right.$ $11.5,1 \mathrm{H}), 4.66\left(\mathrm{~d},{ }^{2} J=11.5,1 \mathrm{H}\right), 4.21(\mathrm{~d}, J=6.7,1 \mathrm{H}), 3.97(\mathrm{dddd}$, $\left.{ }^{3} J_{\mathrm{H}-\mathrm{F}}=13.2, J=6.4,4.4,0.9,1 \mathrm{H}\right), 3.78-3.71(\mathrm{~m}, 1 \mathrm{H}), 3.44(\mathrm{~d}$, $\left.{ }^{4} J_{\mathrm{H}-\mathrm{F}}=6.3,1 \mathrm{H}\right), 2.46\left(\mathrm{dd},{ }^{4} J=7.9,1.2,1 \mathrm{H}\right), 2.24-2.06(\mathrm{~m}, 2 \mathrm{H})$, $1.92-1.81(\mathrm{~m}, 1 \mathrm{H}), 1.78-1.68(\mathrm{~m}, 3 \mathrm{H}) ; \delta_{\mathrm{C}}\left(75 \mathrm{MHz}, \mathrm{CDCl}_{3}\right)$ 137.2, 128.6, 128.2, 127.9, $118.2\left(\mathrm{dd},{ }^{1} J_{\mathrm{C}-\mathrm{F}}=268.1,251.9\right), 94.7$ $\left(\mathrm{dd},{ }^{2} J_{\mathrm{C}-\mathrm{F}}=29.9,20.3\right), 80.2\left(\mathrm{dd},{ }^{2} J_{\mathrm{C}-\mathrm{F}}=30.4,18.0\right), 77.0,75.0$ $\left(\mathrm{d},{ }^{4} J_{\mathrm{C}-\mathrm{F}}=1.8\right), 71.5\left(\mathrm{dd},{ }^{3} J=3.0,3.0\right), 29.6,24.4,15.9 ; \delta_{\mathrm{F}}(282$ $\left.\mathrm{MHz} \mathrm{CDCl}_{3}\right)-109.5\left(\mathrm{ddd},{ }^{2} J_{\mathrm{F}-\mathrm{F}}=259.6, J_{\mathrm{H}-\mathrm{F}}=13.3,5.5,1 \mathrm{~F}\right)$, $(-121.8)-(-122.8)\left(\mathrm{m}\right.$ incl. app. d, $\left.{ }^{2} J_{\mathrm{F}-\mathrm{F}}=259.6,1 \mathrm{~F}\right) ; v_{\max }($ solid $) /$ $\mathrm{cm}^{-1} 3364 \mathrm{br}, 3166 \mathrm{br}, 2913 \mathrm{~s}, 1470 \mathrm{~m}, 1351 \mathrm{~s}, 1210 \mathrm{~s}, 1150 \mathrm{~s}, 1072 \mathrm{~s}$, $1034 \mathrm{~s}, 943 \mathrm{~s}, 915 \mathrm{~s}, 882 \mathrm{~m}, 819 \mathrm{w}, 750 \mathrm{~s}, 699 \mathrm{~s} ; \mathrm{m} / \mathrm{z}\left(\mathrm{CI}^{+}\right) 318(100 \%$, $\left.\left[\mathrm{M}+\mathrm{NH}_{4}\right]^{+}\right), 288$ (8), 258 (3), 241 (14), 228 (5), 212 (4), 192 (5), 163 (10), 108 (3); HRMS $\left(\mathrm{ES}^{+},\left[\mathrm{M}+\mathrm{NH}_{4}\right]^{+}\right.$) calcd for $\mathrm{C}_{15} \mathrm{H}_{22} \mathrm{~F}_{2} \mathrm{O}_{4} \mathrm{~N}$ 318.1511, found 318.1512. Anal. calcd for $\mathrm{C}_{15} \mathrm{H}_{18} \mathrm{~F}_{2} \mathrm{O}_{4}$ : C, 59.99; H, 6.04. Found: C, 59.86; H, 5.90.

Crystal data: $\mathrm{C}_{15} \mathrm{H}_{18} \mathrm{~F}_{2} \mathrm{O}_{4}$, crystal size $0.16 \times 0.13 \times 0.08 \mathrm{~mm}^{3}$, $M=300.29$, monoclinic, $a=10.3624(14) \AA, b=6.6363(9) \AA$, $c=11.0444(15) \AA, \alpha=90^{\circ}, \beta=112.613(2)^{\circ}, \gamma=90^{\circ}, U=$ 701.11(16) $\AA^{3}, T=150(2) \mathrm{K}$, space group $P 2(1), Z=2, \mu$ (Mo $\mathrm{K} \alpha)=0.119 \mathrm{~mm}^{-1}, 5059$ reflections measured, $2397[\mathrm{R}$ (int) $=$ $0.0672]$ which were used in all calculations. Final $\mathrm{R}$ indices $\left[F^{2}>\right.$ $\left.2 \sigma\left(F^{2}\right)\right] \mathrm{R} 1=0.0465, w \mathrm{R} 2=0.0618 ; \mathrm{R}$ indices (all data) $\mathrm{R} 1=$ 0.0684 , wR2 $=0.0683$.

37 (158 mg, 42\%): $R_{f}(50 \%$ ethyl acetate in hexane) $0.12 ; \mathrm{mp}$ $109-112{ }^{\circ} \mathrm{C} ; \delta_{\mathrm{H}}\left(300 \mathrm{MHz}, \mathrm{CDCl}_{3}\right) 7.41-7.33(\mathrm{~m}, 5 \mathrm{H}), 4.91(\mathrm{~d}$, $\left.{ }^{2} J=11.7,1 \mathrm{H}\right), 4.78\left(\mathrm{~d},{ }^{2} J=11.7,1 \mathrm{H}\right), 4.32\left(\mathrm{~d},{ }^{3} J=6.6,1 \mathrm{H}\right)$, 4.01 (ddd, $\left.J_{\mathrm{H}-\mathrm{F}}=20.1,7.8, J=4.8,1 \mathrm{H}\right), 3.86-3.80(\mathrm{~m}, 1 \mathrm{H})$, $3.64\left(\mathrm{~d},{ }^{4} J=5.5,1 \mathrm{H}\right), 2.95(\mathrm{~s}, 1 \mathrm{H}), 2.08-2.00(\mathrm{~m}, 1 \mathrm{H}), 1.96-$ $1.70(\mathrm{~m}, 3 \mathrm{H}), 1.50-1.37(\mathrm{~m}, 2 \mathrm{H}) ; \delta_{\mathrm{C}}\left(75 \mathrm{MHz}, \mathrm{CDCl}_{3}\right) 136.6$, $128.6,128.5,128.2,118.0\left(\mathrm{dd},{ }^{1} J_{\mathrm{C}-\mathrm{F}}=258.8,254.6\right), 94.1(\mathrm{dd}$, $\left.{ }^{2} J_{\mathrm{C}-\mathrm{F}}=26.9,20.3\right), 74.8,74.6\left(\mathrm{dd},{ }^{2} J_{\mathrm{C}-\mathrm{F}}=20.0,17.6\right), 73.3(\mathrm{~d}$ $\left.{ }^{4} J_{\mathrm{C}-\mathrm{F}}=1.8\right), 71.0\left(\mathrm{dd},{ }^{3} J_{\mathrm{C}-\mathrm{F}}=7.8,1.2\right), 27.9\left(\mathrm{~d},{ }^{3} J_{\mathrm{C}-\mathrm{F}}=1.8\right)$, $23.0,18.3 ; \delta_{\mathrm{F}}\left(282 \mathrm{MHz}, \mathrm{CDCl}_{3}\right)(-114.0)-(-114.9)(\mathrm{m}$ incl. app. $\left.\mathrm{d},{ }^{2} J_{\mathrm{F}-\mathrm{F}}=287.8,1 \mathrm{~F}\right),-124.1\left(\mathrm{dddd},{ }^{2} J_{\mathrm{F}-\mathrm{F}}=287.8,{ }^{3} J_{\mathrm{H}-\mathrm{F}}=20.1\right.$, $\left.{ }^{4} J_{\mathrm{H}-\mathrm{F}}=5.5,2.4,1 \mathrm{~F}\right) ; v_{\max }($ solid $) / \mathrm{cm}^{-1} 3364 \mathrm{br}, 3180 \mathrm{br}, 2902 \mathrm{w}$, $1737 \mathrm{~s}, 1453 \mathrm{w}, 1343 \mathrm{w}, 1155 \mathrm{~s}, 1089 \mathrm{~s}, 933 \mathrm{~s}, 867 \mathrm{w}, 728 \mathrm{~s}, 693 \mathrm{~s} ; \mathrm{m} / \mathrm{z}$ $\left(\mathrm{CI}^{+}\right) 318\left(100 \%,\left[\mathrm{M}+\mathrm{NH}_{4}\right]^{+}\right) 302$ (4), 228 (17), 212 (3), 121 (6), 52 (10); HRMS (ES+, $\left[\mathrm{M}+\mathrm{NH}_{4}\right]^{+}$) calcd for $\mathrm{C}_{15} \mathrm{H}_{22} \mathrm{~F}_{2} \mathrm{O}_{4} \mathrm{~N}$ 318.1511, found 318.1515. Anal. calcd for $\mathrm{C}_{15} \mathrm{H}_{18} \mathrm{~F}_{2} \mathrm{O}_{4}$ : C, 59.99; H, 6.04. Found: C, 59.86; H, 5.95.

Crystal data: $\mathrm{C}_{15} \mathrm{H}_{18} \mathrm{~F}_{2} \mathrm{O}_{4}$, crystal size $0.14 \times 0.09 \times 0.06 \mathrm{~mm}^{3}$, $M=300.29$, monoclinic, $a=15.5415(19) \AA, b=6.6332(8) \AA$, $c=13.9404(17) \AA, \alpha=90^{\circ}, \beta=106.126(2)^{\circ}, \gamma=90^{\circ}, U=$ 1380.6(3) $\AA^{3}, T=150$ (2) $\mathrm{K}$, space group $P 2(1) / c, Z=4, \mu$ (Mo $\mathrm{K} \alpha)=0.121 \mathrm{~mm}^{-1}, 9657$ reflections measured, $2430[\mathrm{R}(\mathrm{int})=$ $0.0967]$ which were used in all calculations. Final $\mathrm{R}$ indices $\left[F^{2}>\right.$ $\left.2 \sigma\left(F^{2}\right)\right] \mathrm{R} 1=0.0514, w \mathrm{R} 2=0.0661 ; \mathrm{R}$ indices (all data) $\mathrm{R} 1=$ $0.1050, w R 2=0.0785$. Crude cyclooctenone $20 \mathrm{~b}$ could be used in the dihydroxylation reaction to give diols $\mathbf{3 7}$ and $\mathbf{3 8}$ in $61 \%$ combined yield over two steps from purified RCM precursor $\mathbf{1 9 b}$.
2,2-Difluoro-9-oxa-1 $S^{*}, 5 R^{*}$-bicyclo[3.3.1] nona- $1 S^{*}, 3 R^{*}, 4 R^{*}$ triol 39. Hemiacetal $31(0.080 \mathrm{mmol}, 24 \mathrm{mg})$ was dissolved in ethanol $(1 \mathrm{~mL})$ containing $10 \% \mathrm{Pd}-\mathrm{C}(5 \mathrm{mg})$. The atmosphere was removed and replaced several times by hydrogen from a double balloon, and then the reaction was stirred at room temperature for $23 \mathrm{~h}$. The hydrogen atmosphere was removed in vacuo and replaced with air, and then the catalyst was removed by filtration through celite. Concentration of the filtrate in vacuo afforded $39(16 \mathrm{mg}$, 95\%): $R_{f}\left(100 \%\right.$ ethyl acetate) $0.31 ; \mathrm{mp} 156-158{ }^{\circ} \mathrm{C} ; \delta_{\mathrm{H}}(300$ $\left.\mathrm{MHz}, \mathrm{CD}_{3} \mathrm{OD}\right) 4.06-3.92(\mathrm{~m}, 2 \mathrm{H}), 3.76\left(\mathrm{dd},{ }^{3} J=9.5,6.4,1 \mathrm{H}\right)$, $1.92-1.48$ (env., $6 \mathrm{H}) ; \delta_{\mathrm{C}}\left(100 \mathrm{MHz}, \mathrm{CD}_{3} \mathrm{OD}\right) 117.9\left(\mathrm{dd},{ }^{1} J_{\mathrm{C}-\mathrm{F}}=\right.$ $156.4,150.9), 93.5\left(\mathrm{dd},{ }^{2} J_{\mathrm{C}-\mathrm{F}}=26.8,20.4\right), 73.0,72.9(\mathrm{dd}$, $\left.{ }^{2} J_{\mathrm{C}-\mathrm{F}}=20.4,20.4\right), 72.0\left(\mathrm{~d},{ }^{3} J_{\mathrm{C}-\mathrm{F}}=8.0\right), 28.7\left(\mathrm{~d},{ }^{3} J_{\mathrm{C}-\mathrm{F}}=2.4\right)$, $20.0,18.9 ; \delta_{\mathrm{F}}\left(282 \mathrm{MHz}, \mathrm{CD}_{3} \mathrm{OD}\right)-118.2\left(\mathrm{dd},{ }^{2} J_{\mathrm{F}-\mathrm{F}}=246.7\right.$, $\left.J_{\mathrm{H}-\mathrm{F}}=8.2,1 \mathrm{~F}\right),-129.4\left(\mathrm{ddd},{ }^{2} J_{\mathrm{F}-\mathrm{F}}=246.7, J_{\mathrm{H}-\mathrm{F}}=19.4\right.$, $\left.{ }^{4} J_{\mathrm{H}-\mathrm{F}}=4.3,1 \mathrm{~F}\right) ; v_{\max }($ solid $) / \mathrm{cm}^{-1} 3296 \mathrm{br}, 2964 \mathrm{w}, 1440 \mathrm{w}, 1345 \mathrm{w}$, $1207 \mathrm{~m}, 1116 \mathrm{~m}, 1034 \mathrm{~s}, 996 \mathrm{~s}, 929 \mathrm{~s}, 823 \mathrm{~s} ; \mathrm{m} / \mathrm{z}\left(\mathrm{CI}^{-}\right) 209(30 \%$, $\left.[\mathrm{M}-\mathrm{H}]^{-}\right) 191(11), 170$ (18), 152 (15), 79 (22); HRMS (CI-, $[\mathrm{M}-\mathrm{H}]^{-}$) calcd for $\mathrm{C}_{8} \mathrm{H}_{11} \mathrm{~F}_{2} \mathrm{O}_{4}$ 209.0631, found 209.0630. Anal. calcd for $\mathrm{C}_{8} \mathrm{H}_{12} \mathrm{~F}_{2} \mathrm{O}_{4}$ : C, 45.72; H, 5.75. Found: C, 45.68; H, 5.70.

2,2-Difluoro-9-oxa-1 $S^{*}, 5 R^{*}$-bicyclo[3.3.1] nona- $1 S^{*}, 3 R^{*}, 4 S^{*}$ triol 40. From $37(0.077 \mathrm{mmol}, 23 \mathrm{mg}), 10 \% \mathrm{Pd}-\mathrm{C}(5 \mathrm{mg})$ in ethanol $(1 \mathrm{~mL})$ over $72 \mathrm{~h}$. Filtration through celite and concentration afforded triol 40 (36 mg, 100\%): $R_{f}$ (100\% ethyl acetate) 0.15 ; mp $153-155{ }^{\circ} \mathrm{C} ; \delta_{\mathrm{H}}\left(300 \mathrm{MHz}, \mathrm{CD}_{3} \mathrm{OD}\right) 4.17-4.04$ (env. $2 \mathrm{H}$, containing $4.10\left(\mathrm{ddd}, J_{\mathrm{H}-\mathrm{F}}=21.6,{ }^{3} J_{\mathrm{H}-\mathrm{F}}=8.6, J=4.8,1 \mathrm{H}\right)$ and 4.11-4.09 (m, 1H)), 3.72 (broad s, 1H), 1.90 (broad d, $J=9.6$, $1 \mathrm{H}), 1.80-1.44(\mathrm{~m}, 5 \mathrm{H}) ; \delta_{\mathrm{C}}\left(100 \mathrm{MHz}, \mathrm{CD}_{3} \mathrm{OD}\right) 117.9$ (dd, $\left.{ }^{1} J_{\mathrm{C}-\mathrm{F}}=254.0,254.0\right), 93.8\left(\mathrm{dd},{ }^{2} J_{\mathrm{C}-\mathrm{F}}=26.8,20.4\right), 75.9,72.0$ $\left(\mathrm{dd},{ }^{3} J_{\mathrm{C}-\mathrm{F}}=8.0,1.6\right), 68.8\left(\mathrm{dd},{ }^{2} J_{\mathrm{C}-\mathrm{F}}=21.6,19.2\right), 29.0(\mathrm{~d}$, $\left.{ }^{3} J_{\mathrm{C}-\mathrm{F}}=2.4\right), 23.0,17.7 ; \delta_{\mathrm{F}}\left(282 \mathrm{MHz}, \mathrm{CD}_{3} \mathrm{OD}\right)-(-119.3)-$ $(-120.2)\left(\mathrm{m}\right.$ incl. app. d, $\left.{ }^{2} J_{\mathrm{F}-\mathrm{F}}=247.4,1 \mathrm{~F}\right),-127.3\left(\mathrm{ddd},{ }^{2} J_{\mathrm{F}-\mathrm{F}}=\right.$ $\left.247.4,{ }^{3} J_{\mathrm{H}-\mathrm{F}}=21.3,{ }^{4} J_{\mathrm{H}-\mathrm{F}}=3.8,1 \mathrm{~F}\right) ; v_{\max }($ solid $) / \mathrm{cm}^{-1} 3346 \mathrm{br}$, 2951w, 1647w, 1444w, 1353w, 1204s, 1076s, 1037s, 928s; m/z $\left(\mathrm{CI}^{+}\right) 228\left(100 \%,\left[\mathrm{M}+\mathrm{NH}_{4}\right]^{+}\right) 123$ (6); HRMS (ES ${ }^{+},[\mathrm{M}+$

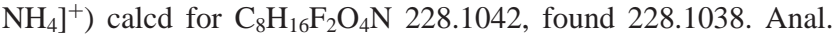
calcd for $\mathrm{C}_{8} \mathrm{H}_{12} \mathrm{~F}_{2} \mathrm{O}_{4}$ : C, 45.72; $\mathrm{H}, 5.75$. Found: C, 45.79; H, 5.80.

2,2-Difluoro-9-oxa-1 $R^{*}, 5 S^{*}$-bicyclo[3.3.1] nona-1 $R^{*}, 3 R^{*}, 4 R^{*}$ triol 41. From $38(0.067 \mathrm{mmol}, 20 \mathrm{mg}), 10 \%$ palladium-on-carbon $(5 \mathrm{mg})$ in ethanol $(1 \mathrm{~mL})$ over $23 \mathrm{~h}$. Filtration through celite and concentration in vacuo afforded triol $41(25 \mathrm{mg}, 91 \%): R_{f}(100 \%$ ethyl acetate) $0.29 ; \mathrm{mp} 57-60{ }^{\circ} \mathrm{C} ; \delta_{\mathrm{H}}\left(300 \mathrm{MHz}, \mathrm{CD}_{3} \mathrm{OD}\right) 3.97$ (broad s, 1H), $3.86\left(\mathrm{ddd}, J_{\mathrm{H}-\mathrm{F}}=13.4,12.5, J=6.9,1 \mathrm{H}\right), 3.53(\mathrm{dt}$, $J=6.9,2.7,1 \mathrm{H}), 2.00-1.90(\mathrm{~m}, 1 \mathrm{H}), 1.72-1.38(\mathrm{~m}, 5 \mathrm{H}) ; \delta_{\mathrm{C}}(400$ $\left.\mathrm{MHz}, \mathrm{CD}_{3} \mathrm{OD}\right) 118.1\left(\mathrm{dd},{ }^{1} J_{\mathrm{C}-\mathrm{F}}=258.0,258.0\right), 94.2(\mathrm{dd}$, $\left.{ }^{2} J_{\mathrm{C}-\mathrm{F}}=31.2,20.0\right), 77.0,72.2\left(\mathrm{dd},{ }^{2} J_{\mathrm{C}-\mathrm{F}}=28.8,19.2\right), 70.6(\mathrm{dd}$, $\left.{ }^{3} J_{\mathrm{C}-\mathrm{F}}=6.0,2.0\right), 30.2,24.8,15.4 ; \delta_{\mathrm{F}}\left(282 \mathrm{MHz}, \mathrm{CD}_{3} \mathrm{OD}\right)-112.7$ $\left(\mathrm{ddd},{ }^{2} J_{\mathrm{F}-\mathrm{F}}=253.5, J={ }_{\mathrm{H}-\mathrm{F}} 12.5,{ }^{4} J_{\mathrm{H}-\mathrm{F}}=3.8,1 \mathrm{~F}\right),-125.1(\mathrm{dd}$, $\left.{ }^{2} J_{\mathrm{F}-\mathrm{F}}=253.5, J_{\mathrm{H}-\mathrm{F}}=13.4,1 \mathrm{~F}\right) ; v_{\max }($ solid $) / \mathrm{cm}^{-1} 3289 \mathrm{br}, 2963 \mathrm{w}$, $1351 \mathrm{~m}, 1205 \mathrm{~m}, 1092 \mathrm{~s}, 1000 \mathrm{~s}, 958 \mathrm{~s}, 894 \mathrm{~s} ; \mathrm{m} / \mathrm{z}\left(\mathrm{CI}^{+}\right) 228(100 \%$, $\left.\left[\mathrm{M}+\mathrm{NH}_{4}\right]^{+}\right)$; HRMS $\left(\mathrm{ES}^{+},\left[\mathrm{M}+\mathrm{NH}_{4}\right]^{+}\right.$) calcd for $\mathrm{C}_{8} \mathrm{H}_{16} \mathrm{~F}_{2} \mathrm{O}_{4} \mathrm{~N}$ 228.1042, found 228.1038. Anal. calcd for $\mathrm{C}_{8} \mathrm{H}_{12} \mathrm{~F}_{2} \mathrm{O}_{4}$ : C, 45.72; H, 5.75. Found: C, 45.84; H, 5.88.

$4 S^{*}$-Acetoxy-3R*-benzyloxy-2,2-difluoro-9-oxa- $1 S^{*}, 5 R^{*}$-bicyclo[3.3.1]nonan-1 $S^{*}$-ol 46. Acetic anhydride $(0.214 \mathrm{~mL}, 2.26 \mathrm{mmol})$, DMAP (16.5 mg, $0.14 \mathrm{mmol})$, and poly(vinylpyridine) $(0.9 \mathrm{mmol}$, $450 \mathrm{mg}$ at $2.0 \mathrm{mmol}$ per gram of loading) were added to a solution of diol 37 (136 mg, $0.45 \mathrm{mmol})$ in DCM (4.5 mL). The suspension was shaken at room temperature for $75 \mathrm{~h}$. TLC analysis showed the reaction was incomplete, so additional acetic anhydride (200 $\mu \mathrm{L}, 2.11 \mathrm{mmol}$ ), DMAP (20 $\mathrm{mg}, 0.17 \mathrm{mmol}$ ), and poly(vinylpyridine) $(320 \mathrm{mg}$ ) were added. The reaction was shaken at room temperature for a further $48 \mathrm{~h}$ until consumption of starting material was observed by TLC. Workup as before afforded $46(138 \mathrm{mg}$, $89 \%$ ) as a white solid: $R_{f}(50 \%$ ethyl acetate in hexane) $0.34 ; \mathrm{mp}$ $28-30{ }^{\circ} \mathrm{C} ; \delta_{\mathrm{H}}\left(300 \mathrm{MHz}, \mathrm{CDCl}_{3}\right) 7.39-7.30(\mathrm{~m}, 5 \mathrm{H}), 5.20$ (ddd, $\left.J=4.9,{ }^{4} J_{\mathrm{H}-\mathrm{F}}=3.8, J=1.5,1 \mathrm{H}\right), 4.76\left(\mathrm{~d},{ }^{2} J=12.4,1 \mathrm{H}\right), 4.73$ $\left(\mathrm{d},{ }^{2} J=12.4,1 \mathrm{H}\right), 4.22(\mathrm{~d}, J=6.7,1 \mathrm{H}), 4.04\left(\mathrm{ddd}, J_{\mathrm{H}-\mathrm{F}}=21.8\right.$, $7.3, J=5.0,1 \mathrm{H}), 3.61(\mathrm{~d}, J=6.4,1 \mathrm{H}), 2.15(\mathrm{~s}, 3 \mathrm{H}), 2.06-1.38$ 
$(\mathrm{m}, 6 \mathrm{H}) ; \delta_{\mathrm{C}}\left(100 \mathrm{MHz}, \mathrm{CDCl}_{3}\right) 170.6,136.7,128.6,128.3,128$, $117.4\left(\mathrm{dd},{ }^{1} J_{\mathrm{C}-\mathrm{F}}=256.4,255.6\right), 94.3\left(\mathrm{dd},{ }^{2} J_{\mathrm{C}-\mathrm{F}}=26.8,20.4\right)$, $73.8-73.2(\mathrm{~m}), 70.8\left(\mathrm{dd},{ }^{3} J_{\mathrm{C}-\mathrm{F}}=9.2,1.6\right), 27.8\left(\mathrm{~d},{ }^{3} J_{\mathrm{C}-\mathrm{F}}=1.6\right)$, 23.0, 21.0, 18.2; $\delta_{\mathrm{F}}\left(282 \mathrm{MHz}, \mathrm{CDCl}_{3}\right)(-116.8)-(-117.8)(\mathrm{m}$, incl. app. d, $\left.{ }^{2} J_{\mathrm{F}-\mathrm{F}}=245.9,1 \mathrm{~F}\right),-127.0\left(\mathrm{ddt},{ }^{2} J_{\mathrm{F}-\mathrm{F}}=245.8\right.$, $\left.J_{\mathrm{H}-\mathrm{F}}=21.8,{ }^{4} J_{\mathrm{H}-\mathrm{F}}=5.2,1 \mathrm{~F}\right) ; v_{\max }(\mathrm{film}) / \mathrm{cm}^{-1} 3434 \mathrm{br}, 2951 \mathrm{~s}$, $1730 \mathrm{~s}, 1367 \mathrm{~s}, 1074 \mathrm{~s}, 908 \mathrm{~s}, 733 \mathrm{~s} ; \mathrm{m} / \mathrm{z}\left(\mathrm{EI}^{+}\right) 342\left(2 \%,[\mathrm{M}+\mathrm{H}]^{+}\right)$ 176 (13), 116 (83), 91 (100), 43 (61); HRMS (ES ${ }^{+},[\mathrm{M}+\mathrm{H}]^{+}$) calcd for $\mathrm{C}_{17} \mathrm{H}_{21} \mathrm{~F}_{2} \mathrm{O}_{5}$ 343.1352, found 343.1356. Anal. calcd for $\mathrm{C}_{17} \mathrm{H}_{20} \mathrm{~F}_{2} \mathrm{O}_{5}$ : C, 59.64; H, 5.89. Found: C, 59.50; H, 5.73.

The ${ }^{13} \mathrm{C}$ NMR spectrum contained a number of weak signals in the 73.8-73.2 ppm region which could not be resolved well, hence the recording of this signal as a multiplet.

$4 R^{*}$-Acetoxy- $3 R^{*}$-benzyloxy- $1 R^{*}$-(dibenzylphosphoryloxy)2,2-difluoro-9-oxa-1 $R *, 5 S^{*}$-bicyclo[3.3.1] nonane 47 and $3 R^{*}$ Benzyloxy-1 $R^{*}$ - (dibenzylphosphoryloxy)-2,2-difluoro-9-oxa$1 \boldsymbol{R}^{*}, \mathbf{5} S^{*}$-bicyclo[3.3.1]nonan-4 $\boldsymbol{R}^{*}$-ol 44. NaHMDS $(0.54 \mathrm{mmol}$, $317 \mu \mathrm{L}$ of a $1.7 \mathrm{M}$ solution in THF) was added dropwise to a solution of $46(0.49 \mathrm{mmol}, 168 \mathrm{mg})$ in $\mathrm{THF}(10 \mathrm{~mL})$ at $0{ }^{\circ} \mathrm{C}$ and stirred at this temperature for $1 \mathrm{~h}$. Tetrabenzyl pyrophosphate $(0.54$ $\mathrm{mmol}, 290 \mathrm{mg}$ ) was added, and the reaction was allowed to warm to room temperature over $2 \mathrm{~h}$, then stirred for $18 \mathrm{~h}$ after which a white precipitate was observed. The reaction was quenched with $\mathrm{pH} 7$ buffer $(10 \mathrm{~mL})$ and extracted with ethyl acetate $(2 \times 50 \mathrm{~mL})$. The combined organic extracts were washed with brine $(20 \mathrm{~mL})$, dried $\left(\mathrm{MgSO}_{4}\right)$, filtered, and concentrated in vacuo to give a gray paste which was purified (flash chromatography, silica, 50\% ethyl acetate in hexane) to afford $47(188 \mathrm{mg}, 64 \%): R_{f}$ (ethyl acetate) $0.60 ; \delta_{\mathrm{H}}\left(300 \mathrm{MHz}, \mathrm{CDCl}_{3}\right) 7.38-7.28(\mathrm{~m}, 15 \mathrm{H}), 5.22-5.18(\mathrm{~m}$, 1H), 5.17-5.05 (m, 4H), $4.75(\mathrm{~s}, 2 \mathrm{H}), 4.35\left(\mathrm{~d},{ }^{3} \mathrm{~J}=6.6,1 \mathrm{H}\right), 4.05$ $\left(\mathrm{ddd},{ }^{3} J_{\mathrm{H}-\mathrm{F}}=20.5, J=7.0,5.0,1 \mathrm{H}\right), 2.56-2.40(\mathrm{~m}, 1 \mathrm{H}), 2.16-$ 1.79 (envelope, 6H), $2.06(\mathrm{~s}, 3 \mathrm{H}), 1.52-1.36(\mathrm{~m}, 2 \mathrm{H}) ; \delta_{\mathrm{C}}(100$ $\left.\mathrm{MHz}, \mathrm{CDCl}_{3}\right) 170.5,136.6,136.0\left(\mathrm{~d},{ }^{3} J_{\mathrm{C}-\mathrm{P}}=8.8\right), 135.7(\mathrm{~d}$, $\left.{ }^{3} J_{\mathrm{C}-\mathrm{P}}=8.0\right), 128.6,128.5,128.5,128.4,128.4,128.3,128.1,128.0$, $127.9,116.0\left(\mathrm{ddd},{ }^{2} J_{\mathrm{F}-\mathrm{F}}=264.7,256.9,{ }^{3} J_{\mathrm{C}-\mathrm{P}}=6.8\right), 99.8(\mathrm{ddd}$, $\left.{ }^{2} J_{\mathrm{C}-\mathrm{F}}=27.2,18.4,{ }^{2} J_{\mathrm{C}-\mathrm{P}}=7.2\right), 75.8,73.3,73.0\left(\mathrm{ddd},{ }^{2} J_{\mathrm{C}-\mathrm{F}}=\right.$ $\left.21.6,17.6,{ }^{4} J_{\mathrm{C}-\mathrm{P}}=1.6\right), 70.4\left(\mathrm{~d},{ }^{3} J_{\mathrm{C}-\mathrm{F}}=9.6\right), 69.7\left(\mathrm{dd},{ }^{2} J_{\mathrm{C}-\mathrm{P}}=\right.$ $\left.6.4,{ }^{6} J_{\mathrm{C}-\mathrm{F}}=1.6\right), 69.4\left(\mathrm{~d},{ }^{2} J_{\mathrm{C}-\mathrm{P}}=6.4\right), 27.8,22.6,20.9,18.4 ; \delta_{\mathrm{F}}$ $\left(282 \mathrm{MHz}, \mathrm{CDCl}_{3}\right)(-117.7)-(-118.5)(\mathrm{m}, 1 \mathrm{~F}),-124.3\left(\mathrm{ddd},{ }^{2} J_{\mathrm{F}-\mathrm{F}}\right.$ $\left.=245.9, J_{\mathrm{H}-\mathrm{F}}=20.5, J=5.2,1 \mathrm{~F}\right) ; \delta_{\mathrm{P}}\left(121 \mathrm{MHz}, \mathrm{CDCl}_{3}\right)-8.8$ (quintet, ${ }^{3} J_{\mathrm{H}-\mathrm{P}}=7.3$ ); $v_{\max }(\mathrm{film}) / \mathrm{cm}^{-1} 3472 \mathrm{w}, 2955 \mathrm{~s}, 1738 \mathrm{~s}, 1496 \mathrm{~s}$, $1455 \mathrm{~s}, 1371 \mathrm{~s}, 1243 \mathrm{~s}, 1017 \mathrm{~s}, 873 \mathrm{w}, 738 \mathrm{~s} ; \mathrm{m} / \mathrm{z}\left(\mathrm{CI}^{+}\right) 603(28 \%,[\mathrm{M}$ $+\mathrm{H}^{+}$) $513(5), 360$ (7), 125 (13), 108 (51), 106 (100); HRMS $\left(\mathrm{ES}^{+},[\mathrm{M}+\mathrm{H}]^{+}\right.$) calcd for $\mathrm{C}_{31} \mathrm{H}_{34} \mathrm{~F}_{2} \mathrm{O}_{8} \mathrm{P} 603.1954$, found 603.1955 . Traces of deprotected 44 (16 $\mathrm{mg}, 6 \%)$ were also produced, as reported previously.

2,2-Difluoro-3R*,4S*-dihydroxy-9-oxa- $1 S^{*}, 5 R^{*}$-bicyclo[3.3.1]nonanyl-1 $S^{*}$-phosphate Ammonium Sodium Salt 48. Hydrogenolysis. $10 \%$ Palladium-on-carbon $(64 \mathrm{mg})$ was added to a solution of $47(0.28 \mathrm{mmol}, 170 \mathrm{mg})$ in ethanol $(5.6 \mathrm{~mL})$. The apparatus was pump-purged with hydrogen from a double balloon, and the reaction was stirred under hydrogen at room temperature for $90 \mathrm{~h}$. The solution was filtered through celite, and the filtrate was concentrated in vacuo $(98 \mathrm{mg}, 100 \%):\left\{{ }^{1} \mathrm{H}\right\} \delta_{\mathrm{F}}(282 \mathrm{MHz}$, $\left.\mathrm{CD}_{3} \mathrm{OD}\right)-116.3\left(\mathrm{~d},{ }^{2} J_{\mathrm{F}-\mathrm{F}}=243.2,1 \mathrm{~F}\right),-121.2\left(\mathrm{~d},{ }^{2} J_{\mathrm{F}-\mathrm{F}}=243.2\right.$, $1 \mathrm{~F}) ; \delta_{\mathrm{P}}\left(121 \mathrm{MHz}, \mathrm{CD}_{3} \mathrm{OD}\right)(+8)-(-12)($ br. $\mathrm{m}) ; \mathrm{m} / \mathrm{z}\left(\mathrm{ES}^{-}\right) 331$ $\left(100 \%,[\mathrm{M}-\mathrm{H}]^{-}\right) 289$ (15), 167 (17), 89 (46), 75 (44); HRMS $\left(\mathrm{ES}^{-},[\mathrm{M}-\mathrm{H}]^{-}\right)$calcd for $\mathrm{C}_{10} \mathrm{H}_{14} \mathrm{~F}_{2} \mathrm{O}_{8} 331.0400$, found 331.0396 .

Acetate Cleavage and Bis(triethylammonium) Salt Formation. The crude acid $(0.28 \mathrm{mmol}, 98 \mathrm{mg})$ was taken up in a mixture of methanol, water, and triethylamine $(5.9 \mathrm{~mL}, 5: 2: 1)$ and stirred at room temperature for $22 \mathrm{~h}$. The organic solvents were removed in vacuo, then the residue was freeze-dried to afford the crude bis(triethylammonium) salt: $\delta_{\mathrm{F}}\left(282 \mathrm{MHz}, \mathrm{CD}_{3} \mathrm{OD}\right)-119.7(\mathrm{~d}$, $\left.{ }^{2} J_{\mathrm{F}-\mathrm{F}}=245.0,1 \mathrm{~F}\right),-124.2\left(\mathrm{dd},{ }^{2} J_{\mathrm{F}-\mathrm{F}}=245.0, J_{\mathrm{H}-\mathrm{F}}=20.8,1 \mathrm{~F}\right)$; $\delta_{\mathrm{P}}\left(121 \mathrm{MHz}, \mathrm{CD}_{3} \mathrm{OD}\right)-3.9(\mathrm{~s}) ; \mathrm{m} / z\left(\mathrm{ES}^{+}\right) 493\left(58 \%,[\mathrm{M}+\mathrm{H}]^{+}\right)$ 392 (97), 242 (5), 102 (100), 74 (35); HRMS (ES,$[\mathrm{M}+\mathrm{H}]^{+}$) calcd for $\mathrm{C}_{20} \mathrm{H}_{43} \mathrm{~F}_{2} \mathrm{~N}_{2} \mathrm{O}_{7} \mathrm{P}$ 493.2849, found 493.2851.

Purification and Ammonium Sodium Salt Formation. Flash chromatography (silica, ethanol/water/35\% aqueous ammonia (5:3:1)) afforded ammonium sodium salt $48(60 \mathrm{mg}, 66 \%): R_{f}$ (ethanol/water/35\% aqueous ammonia (5:3:1)) 0.13 ; mp 137$139{ }^{\circ} \mathrm{C} ; \delta_{\mathrm{H}}\left(400 \mathrm{MHz}, \mathrm{D}_{2} \mathrm{O}\right) 4.35\left(\mathrm{ddd}, J_{\mathrm{H}-\mathrm{F}}=21.5,8.1, J=4.8\right.$, $1 \mathrm{H}), 4.33-4.31(\mathrm{~m}, 1 \mathrm{H}), 3.98-3.92(\mathrm{~m}, 1 \mathrm{H}), 2.28\left(\mathrm{ddd},{ }^{2} J=14.2\right.$, $J=14.0,7.3,1 \mathrm{H}), 2.06\left(\mathrm{dd},{ }^{2} J=14.2, J=5.4,1 \mathrm{H}\right), 1.95-1.75$ $(\mathrm{m}, 2 \mathrm{H}), 1.71-1.60(\mathrm{~m}, 1 \mathrm{H}), 1.57-1.50(\mathrm{dd}, J=14.0,5.3,1 \mathrm{H})$; $\delta_{\mathrm{C}}\left(100 \mathrm{MHz}, \mathrm{D}_{2} \mathrm{O}\right) 117.4\left(\mathrm{dd},{ }^{1} J_{\mathrm{C}-\mathrm{F}}=256.4,250.1\right), 97.2(\mathrm{ddd}$, $\left.{ }^{2} J_{\mathrm{C}-\mathrm{F}}=25.6,18.4,{ }^{2} J_{\mathrm{C}-\mathrm{P}}=7.2\right), 76.8,71.4\left(\mathrm{dd},{ }^{3} J_{\mathrm{C}-\mathrm{F}}=8.0,1.6\right)$, $68.4\left(\mathrm{dd},{ }^{2} J_{\mathrm{C}-\mathrm{F}}=20.8,18.4\right), 27.6,22.3,17.5 ; \delta_{\mathrm{F}}\left(282 \mathrm{MHz}, \mathrm{D}_{2} \mathrm{O}\right)$ $(-118.4)-(-119.4)\left(\mathrm{m}\right.$. incl. app. d, $\left.{ }^{2} J_{\mathrm{F}-\mathrm{F}}=243.1,1 \mathrm{~F}\right),-123.7$ $\left(\mathrm{ddd},{ }^{2} J_{\mathrm{F}-\mathrm{F}}=243.1, J_{\mathrm{H}-\mathrm{F}}=21.5,{ }^{4} J_{\mathrm{H}-\mathrm{F}}=5.9,1 \mathrm{~F}\right) ; \delta_{\mathrm{P}}(121 \mathrm{MHz}$, $\left.\mathrm{D}_{2} \mathrm{O}\right)-4.1(\mathrm{~s}) ; \nu_{\max }(\mathrm{film}) / \mathrm{cm}^{-1} 2952 \mathrm{br}, 1444 \mathrm{w}, 1361 \mathrm{w}, 1167 \mathrm{~m}$, 1078s, 1040s, 910s, 808s, 751s, 685w; m/z (ES $\left.{ }^{-}\right) 289(4 \%,[\mathrm{M}-$ $\left.\mathrm{H}]^{-}\right) 273$ (5), 183 (3), 125 (56), 97 (100); HRMS (ES ${ }^{-},[\mathrm{M}-$ $\mathrm{H}^{-}$) calcd for $\mathrm{C}_{8} \mathrm{H}_{12} \mathrm{~F}_{2} \mathrm{O}_{7} \mathrm{P} 289.0294$, found 289.0297. Anal. calcd for $\mathrm{C}_{8} \mathrm{H}_{15} \mathrm{~F}_{2} \mathrm{NO}_{7} \mathrm{NaP}: \mathrm{C}, 29.18 ; \mathrm{H}, 4.56 ; \mathrm{N}, 4.26$. Found: $\mathrm{C}, 29.48$; $\mathrm{H}, 4.32$; N, 4.27.

Acknowledgment. We thank the EPSRC for studentships (J.A.L.M., L.M.), the EPSRC Mass Spectrometry Service (Swansea) for accurate mass measurements, Dr. Roland Wende (Umicore) for a donation of the Neolyst catalyst, and Dr. A. Caravano (Sanofi-Aventis) and Professor R. A. Field (University of East Anglia) for helpful discussions.

Supporting Information Available: Experimental procedures for 11a, 11b, 13, 14, 26a-27b, 30, 44, and 45; NMR spectra $\left({ }^{1} \mathrm{H}\right.$, $\left.{ }^{13} \mathrm{C},{ }^{19} \mathrm{~F},{ }^{31} \mathrm{P}\right)$ for $11 \mathrm{a}, 11 \mathrm{~b}, 13,14,16-19 \mathrm{a}, 26 \mathrm{a}-27 \mathrm{~b}, 33,34,44$, 45, and 47; Cartesian coordinates and energies for RHF 6-31G* optimized structures for lowest-energy conformers of 39-41, and calculated energies (RHF 6-31+G**) for 39-41. This material is available free of charge via the Internet at http://pubs.acs.org.

JO0620258 